\title{
Issues in conserving 'orphan heritage' in Asia: WWII battlefield conservation in Hong Kong and Malaysia
}

\author{
Yi-Wen Wang ${ }^{1 *} \mathbb{D}$, Jesse DiMeolo ${ }^{2}$ and Gao Du ${ }^{3}$
}

\begin{abstract}
Wars and conflict have existed since the beginning of time. Most battlefield conservation work is done for battlefields that lie in the borders of the nations that were involved, thus fostering citizens' personal ties with the site and their national identities. However, some areas of the world suffer from conservation neglect because of the distance and separation between the battlefield's location and the country to which it is relevant, thus creating a dislocated appreciation of heritage described by Price (J Confl Archaeol 1:181-196, 2005) as 'orphan heritage'. This paper questions the extent to which post-colonial nations are willing to protect and conserve World War II battlefields on their soil. It examines two battlefields in Asia-the Gin Drinkers' Line in Hong Kong, China, and the Green Ridge battlefield in Kampar, Malaysia - that have been the subject of campaigns to recognise their transnational heritage value. Both battles involved multinational Allied forces led by the British against Japanese troops. A combination of political and economic factors has influenced how the two battlefields are understood and appreciated by citizens and local governments in the host nations. The paper delineates how these two Asian battlegrounds, which are relatively unknown to the general public, have been brought to the public's attention and by whom as well as how the local governments have handled the demand to safeguard the battlefields. We argue that the global nature of WWII makes its commemoration geographically challenging and politically contentious. The WWII battlefields in Asia attest to the historical authenticity of past conflicts and thus should be conserved as neutrally as possible. The successful protection of battlefields in Malaysia and Hong Kong thus far can be largely attributed to grassroots initiatives, pressure from stakeholder countries, such as the UK, and academic research whereby the significance of the battleground is made known to people in Hong Kong and Malaysia. With public support, responsible government leadership and a shared understanding of their importance as transnational heritage, WWII battlefields can help calm bitter resentment and promote reconciliation.
\end{abstract}

Keywords: World war II, battlefields, conservation, transnational heritage, post-colonial countries

\section{Introduction}

Writing and historiography regarding the Second World War (WWII) have revolved around the horrors of war in Europe but provided relatively little information about the Asian theatre of war. Certainly, this sustained attention on Europe may stem from the high number of

\footnotetext{
* Correspondence: yiwen.wang@xjtlu.edu.cn

'Department of Urban Planning \& Design, Xi'an Jiaotong-Liverpool University, 111 Ren'ai Road, Dushu Lake Higher Education Town, Suzhou Industrial Park, Suzhou 215123, Jiangsu Province, China

Full list of author information is available at the end of the article
}

deaths and the level of atrocity perpetrated by Nazi Germany, the major Axis power. However, the great extent to which the two major Allied nations-the US and the UK-have committed themselves to commemorating war deaths may have been equally decisive in this matter. Various groups and individuals, including national and local governments, charitable trusts, non-profit organisations, civil or veteran communities, and families of fallen soldiers, have initiated different forms of commemoration and remembrance (Danilova 2015; Edwards

\section{Springer Open}

() The Author(s). 2021 Open Access This article is licensed under a Creative Commons Attribution 4.0 International License, which permits use, sharing, adaptation, distribution and reproduction in any medium or format, as long as you give appropriate credit to the original author(s) and the source, provide a link to the Creative Commons licence, and indicate if changes were made. The images or other third party material in this article are included in the article's Creative Commons licence, unless indicated otherwise in a credit line to the material. If material is not included in the article's Creative Commons licence and your intended use is not permitted by statutory regulation or exceeds the permitted use, you will need to obtain permission directly from the copyright holder. To view a copy of this licence, visit http://creativecommons.org/licenses/by/4.0/. 
2015). Neither the US nor the UK have experienced occupation by foreign powers in modern history, nor were major battles conducted on their soil during the two global wars. The sites at which American and British soldiers fought and died in combat are often thousands of miles away from the place where their deaths are commemorated in the form of memorial plaques, cemeteries or ceremonies. ${ }^{1}$ In contrast, the events of WWII in the Asia-Pacific region, which marked the climax of Japan's empire-building, are relatively under-represented in current commemoration and remembrance practices. This is somewhat paradoxical, as military deaths for Japan and China, for instance, vastly outnumbered those for the US and the UK ${ }^{2}$ (Harrison 1998; Mitter 2013). The general neglect of the events and repercussions of the war in Asia in the historical writing and commemoration of WWII suggests the general reluctance of Asian countries to remember the war (Saito 2016).

This paper examines areas of the globe that suffer from poor battlefield conservation efforts because the physical separation of the battlefield from its stakeholders creates ambiguity in the 'ownership' of such heritage. Stakeholders who feel place attachment to a battlefield in a foreign land where their loved ones fought and perished experience a dislocated appreciation of their heritage, which has been described as 'orphan heritage' by Price $(2005,181)$. Most battlefield conservation work has been carried out in places within national borders where citizens have strong personal ties and collectively identity with the battle (Banks and Pollard 2011; Waterton and Dittmer 2016). For example, driven by patriotism, the US has large interest groups and charities that work together to conserve Civil War

\footnotetext{
${ }^{1}$ For instance, Britain witnessed a massive wave of public commemoration in the aftermath the First World War in which tens of thousands of war memorials were erected, almost one in every single British village, town and city to commemorate those who had been buried abroad-as a result of the country's non-repatriation policy-where they had fallen. The Imperial (now Commonwealth) War Graves Commission also erected a large number of war memorials in churchyards and cemeteries in Britain to mark the graves of soldiers of various nationalities who died during the two world wars. These 'memorials at home' were 'empty tombs and "became the foci for grief and remembrance' (Historic England 2017b: 8). This movement of commemoration was sparked by the erection of the cenotaph in Whitehall, London (1919-20), which became Britain's major national war memorial to the dead in both world wars and in subsequent armed conflicts (Historic England 2017b). Similarly, the US set up the National World War II Memorial in Washington, D.C. Completed and opened to the public in 2004, this national memorial honours the 16million Americans who served in the US armed forces during the war, more than 400,000 of whom died, and the citizens who supported the war efforts from home (see the official website www.wwiimemorial. com).

${ }^{2}$ The military deaths from 1939 to 1945 in China and Japan, respectively reached 2.2 and 1.2 million, whereas the fatalities in the US and UK, respectively reached 405,000 and 329,000 , as estimated by CNN (Mitter 2015).
}

battlefields for the country's common good. The Civil War Charitable Trust Fund, a non-profit organisation in the US, receives donations from citizens and has now used that money to buy upwards of 50,000 acres of battlefields, promising to preserve all of this land from future development (Campi 2019). These protected areas include Vicksburg, Chickamauga, Kennesaw Mountain, New Hope Church, Antietam, Fort Sumter, Second Manassas and Petersburg Battlefields. In contrast to intrastate conflicts, WWII, as a global war, involved more than 30 countries and 100 million military personnel forming international troops who marched across the borders of both countries and continents. The commemoration of war deaths is not only geographically challenging but also politically contentious. Numerous battlefields have turned into 'orphan heritage' sites due to the disjunction between the stakeholder groups who ascribe value to a battlefield and those who own or live on the battlefield.

This paper aims to advance the understanding of WWII commemoration in Asia, which has been underrepresented in the global history of the war. Focusing on battlefields, it questions the extent to which postcolonial nations in Asia are willing to protect and conserve WWII battlefields on their soil. A combination of political and economic factors can affect how 'orphan heritage' battlefields are understood or appreciated by citizens and local governments in host nations. Potential financial gain from land development and real estate is widely perceived as a threat to the preservation of such battlefields. Concurrently, political factors are at play because the politics of war commemoration are invariably multilateral and, consequently, contentious. Drawing on the idea of 'orphan heritage' (Price 2005), this paper examines two WWII battlefields that have been the subject of campaigns espousing their transnational heritage value - the battlefield of the Gin Drinkers' Line in Hong Kong, China, and the Green Ridge battlefield in Kampar, Malaysia. A close examination of these two cases can yield new insight into how these two Asian battlefields, which are relatively unknown to the general public have been brought to the public's attention and by whom as well as how the governments of the two host nations have handled the demand to safeguard the battlefields.

The two cases are relevant and suitable for comparison for a multitude of reasons. Their commonalities come from the fact that both Hong Kong (1841-1997) and Malaya (1824-1957) were colonies of the British Empire during the war; both battles took place around the same time, in December 1941, and occurred early on in the initial advancements of the Japanese troops; both battles involved a wide array of soldiers from various Allied countries as well as from among locals who gathered on the battlefield to fight for different reasons; and, most 
importantly, the cry for conserving these battlefields has mainly come from individuals of the host nation who have little personal attachment to those who perished during the battles (Lai et al. 2009; Muzaini 2013). While both China and Malaysia have been reluctant to accord heritage status to the battlefields in question, this shared reluctance derives from their very different historical trajectories during post-colonial independence and, consequently, their political undertones. It also raises questions as to why local citizens and politicians feel differently about WWII 'orphan heritage' on their soil and what role the international community can play in protecting WWII battlefields as part of transnational heritage. These are tough questions to answer, but a thorough examination of current practices can shed light on the issues involved. To better situate the two cases in the existing scholarly discussion, the following section first provides an overview of the literature on battlefield conservation and distinguishes WWII battlefields from historic battlefields and other forms of war commemoration.

\section{Battlefields as heritage}

The idea to protect, conserve or accord heritage status to battlefields emerged in the 1990s, when scholars and practitioners in various fields concurrently turned their attention towards sites of human death and suffering. Battlefields have come into the spotlight of academic discussions as a result of the recent surge of interest in war commemoration and 'dark' heritage sites. Various strands of thought emerged at the end of the century, providing theoretical and analytical framing for the management of sites associated with human death and suffering (Hartmann 2014; Ashworth and Isaac 2015). Studies in the heritage field use various terms to describe such sites, including 'heritage that hurt', 'heritage of atrocity', 'dissonant heritage', 'difficult heritage', 'negative heritage' and 'uncomfortable heritage' (Tunbridge and Ashworth 1996; Uzzell and Ballantyne 1998; Meskell 2002; Logan and Reeves 2009; Merrill and Schmidt 2011; Macdonald 2015; Pendlebury et al. 2018). Conversely, tourism studies commonly couched the fascination with these sites as 'dark tourism' (Stone 2006; Lennon and Foley 2010) or use the word 'thana-tourism' (Seaton 1996), which questions the fascination, motivation and experience of tourists to visit battlefields or sites of death. The two relevant areas of study-heritage and tourism-deal with the supply and demand side of dark heritage, and battlefields are situated at the intersection of these two fields, as they are reminders of the painful past that should be managed and are also places that appeal to tourists for different reasons.

Parallel to the rise in interest in the 1990s in places of death and suffering, there was a growing interest in the archaeology of warfare, which consequently made 'historic battlefields' a distinct category of archaeological sites that would be excavated and protected (Carman and Carman 2009). Several developed countries began to designate historic battlefields as heritage assets of national importance. England, for instance, launched in 1995 the Register of Historic Battlefields to provide statutory protection for those sites registered on the national heritage inventory (Historic England 2017a). When these battlefields are given heritage status, their particular associated battles are punctuated as momentous national historical events to be remembered (Banks and Pollard 2011). The conservation of historic battlefields has relatively little to do with preserving material relics that evidence that an armed conflict took place. Instead, it involves the tasks of marking the location of the battle on the ground by putting up memorials, protecting the field from development through planning regulations or compulsory purchase orders, and staging battle re-enactments for edutainment purposes (Ryan 2007; Carman and Carman 2009; Banks and Pollard 2011). The protection of historic battlefields is primarily symbolic and done to captivate the imagination since memories of the bloody battles are often too distant to be recalled. In contrast, the protection of battlefields of the recent past (especially the two world wars of the last century) presents a difficult dilemma since material evidence remains visible on the landscape and memories linger in the minds of many living individuals.

\subsection{What distinguishes WWII battlefields?}

Unlike more distant historic battle sites, WWII battlefields bear physical traces of the war, ranging from military installations and fortifications to bombed-out, crumbling ruins and scarred landscapes. WWWII battlefield conservation has revolved around the commemoration of war deaths and the preservation of material evidence of the war, which form part of the broader concept of 'war heritage'. Commemoration is primarily associated with the wars of the last century, particularly WWII, which has been commemorated in various ways since the very moment the war ended (Reeves et al. 2016). WWII holds a unique place in the public's memory partly because the atrocities were recorded in detail and are accessible to the general public. This painful past is repeatedly brought alive through acts of curated remembrance in varying forms. Commemorative acts can be broadly divided into government-led and citizen-led initiatives, although the former have been arguably more prevalent than the latter. The existing literature has extensively explored governments' roles in constructing narratives of the war and how it should be remembered. Emphasis has been placed on various mechanisms available for heritage authorities and educational institutions to deploy, including the erection of memorial halls, museums or monuments; the celebration of key wartime 
events (for example, D-Day, VE-day, and VJ day); the standardisation of textbooks; the organisation of school trips; and the establishment of a national online database of war deaths for digital commemoration efforts (Muzaini and Yeoh 2005; Muzaini 2006; Winter 2012; Bernstein 2015; Hopkins-Weise and Czechura 2019). More recently, an emerging body of literature has examined public and private commemoration activities initiated by individuals, interest groups and travel agencies to satisfy the desire for such memorialisation. Among these activities, battlefield pilgrimages undertaken by veterans or the families and friends of perished soldiers are the most common type of citizen-led commemoration, representing the public's initiative instead of that of the government (Ryan 2007; Edwards 2015; Reeves et al. 2016).

Representing the exact location of armed conflicts and war deaths, battlefields are ascribed heritage value for their authentic location. Unlike burial sites such as cemeteries, battlefields provide a focal point of the bloodshed. Although both types of locations offer a place for commemorating the war dead, they prompt emotional engagement and inflame sentiment regarding different causes. Likewise, war memorials or cemeteries may crystallise and perpetuate painful memories of war, but battlefields are themselves emotionally charged landscapes. Battlegrounds are the carrier and repository of personal and collective memories of war. Similar to war relics such as remnants of military installations and bombed buildings, a once blood-soaked field can evoke memories and bear meaning. This is best exemplified by battlefield pilgrimages, which represent a compulsion or desire to be closer to the historical authenticity of the war, a state that is attainable only by visiting the battlefield in person, attending memorial ceremonies in situ and gazing at the battleground or relics (Edwards 2015; Reeves et al. 2016). Symbolising the historical authenticity of past conflicts and fatalities, WWII battlefields not only are a vital place for remembering past sacrifices but also serve as a poignant reminder of the destruction of war. As noted by Banks and Pollard (2011, 131), 'without the battlefields we are left with the documentary accounts only, and in many cases, these were written long after the events, and often with a partisan perspective'. On this account, battlefields should be protected as neutrally as possible to allow society to remember the past in the most accurate way. As time progresses, generations will pass and memories will fade, leaving us only with narratives that should be written on the former battleground in an unbiased and reconciled manner.

Nonetheless, the extensive geographical coverage of warfare has posed a key challenge for battlefield conservation. Unlike the preservation of other tangible heritage assets, such as temples, palaces, historic buildings, and landscaped gardens, battlefield conservation is a complicated task. On the one hand, compared to most archaeological sites, which accumulate evidence of past activities over decades, centuries, or millennia, traces of past battles last for a relatively short time (Banks and Pollard 2011). On the other hand, marking the boundary of a battleground and designating it as heritage can be tricky because it is difficult to track and analyse how thousands of troops moved across hundreds of miles in a fight lasting several days or to several months (The Hong Kong Institute of Surveyors 2011). Advancements in threedimensional AutoCAD mapping technologies and existing technologies such as aerial photography have made it increasingly easier to map land. Making up for the lost time is vital; the field of defence heritage is relatively new, and today's researchers do not necessarily possess surveying skills or the requisite spatial knowledge (Bull and Panton 2000; Banks and Pollard 2011). While the practice of conserving battlefields is still in its infancy, researchers have explored various techniques and approaches to excavating and mapping underground tunnel networks and military structures above the ground, such as pillboxes (concrete blockhouses with firing holes for machine guns) (Price 2005; The Hong Kong Institute of Surveyors 2011).

The other key challenge of WWII battlefield conservation lies in political motivations and the controversies that conservation can provoke. More often than not, conferring heritage status to a battlefield is motivated by a political agenda-i.e. to forge a distinct national identity and spark patriotic pride (Reeves et al. 2016). In addressing the issues involved in protecting and managing WWI battlefields and cemeteries ${ }^{3}$ in Europe, Price (2005, 181-182) coins the term 'orphan heritage' to draw attention to the neglect of war heritage due to the

\footnotetext{
${ }^{3}$ Although cemetery sites also qualify as 'orphan heritage' according to Price's elaboration, a wider discussion on wartime burial grounds would blur the focus of this paper on battlefields and would thus exceed its intended scope. Of course, cemeteries share similarities with battlefields in their critical role as sites for remembrance and commemoration and are also marked by a spatial separation between stakeholders and the location of their heritage. Nonetheless, cemeteries and battlefields differ markedly in their nature. Unlike battlefields, which represent authentic sites of past events, cemeteries derive their authenticity from being the final resting place of human remains. Remains from a war continue to be uncovered from battlefields after the war. Both war-time burials and the post-war reburial of remains are subject to the legislation of the country in which those remains were found and the nationality of the individuals uncovered. Excluding cemeteries from the current discussion of orphan heritage can avoid unnecessary complication and confusion in attempting to understand the importance of battlefield conservation. Moreover, military cemeteries established during the two world wars are the result of international agreements on ceding territory for burial sites, since the staggering number of fatalities made repatriation impractical, if not impossible. In this case, the stakeholders of heritage cemeteries indisputably own the location (though it may be in a foreign country). Over the course of time or as a result of regime change, war graves and cemeteries may suffer wilful neglect but, as ceded territory, they should never face the threat of property development or be cleared for building construction-the almost inevitable fate of numerous battlefields (Price 2005).
} 
spatial separation between those who care and are interested in protecting a battlefield 'by reason of ownership of heritage' and those who claim legitimacy in using or appropriating the battlefield 'by reason of ownership of location'. Price's 'orphan heritage' has distinctly accentuated the paradoxical disjunction of the 'ownership' of heritage and location, despite the ambiguity in the use of the word 'orphan'4 (Ferguson 2007; Banks and Pollard 2011).

For a battleground that may have relatively little relevance to the host nation's identity and pride, the motives for protecting it rely on a shared international understanding of the world wars and the human virtues of compassion and benevolence. It is unsurprising that most of the WWII battlefields in Asia, as transnational 'orphan heritage' sites of the war, have inevitably suffered neglect. Most Asian countries are reluctant to commemorate WWII and safeguard these battlefields, partly because the history of the war in these nations is inextricably intertwined with their colonised past (Blackburn 2010). The two battlefields examined in this paper exemplify the political circumstances that caused the reluctance of post-colonial states in Asia to protect their battlefield heritage sites in the early years after the war and show that the compassion and initiative of individuals and interest groups eventually overcame this political reluctance and resolved the public ambivalence towards WWII battlefields in their homeland.

\section{WWII battlefields in Hong Kong and Malaysia}

Although China had been fighting against Japanese troops' invasion since 1937, it was not until the Japanese attacked Pearl Harbor on 7 December 1941 and then launched full-scale attacks on several US military bases and British colonies that the region entered the global war (Mitter 2013). Both Hong Kong and Malaysia bore the brunt of the first wave of Japanese offensives (19411942) (Fig. 1) (Horner 2002). The two battlefields examined here-the Gin Drinkers' Line in Hong Kong and the Green Ridge battlefield in Kampar, Perak State, Malaysia-are two of several locations where the Battle of Hong Kong (8-25 Dec 1941) and the Battle of Kampar (30 Dec 1941 to 2 Jan 1942), respectively, took place in the Asia-Pacific theatre in WWII.

\subsection{The Gin Drinkers' Line in Hong Kong and the Green Ridge in Kampar, Malaysia}

The Gin Drinkers' Line (Fig. 2) saw action in the early days of the Battle of Hong Kong after the Japanese

\footnotetext{
${ }^{4}$ Ferguson (2007) points out that the word 'orphan' may be interpreted literally and, thus, the term 'orphan heritage' may be misunderstood as a place where no legitimate owners can officially claim heritage or as a place that no countries would wish to identify with.
}

conducted an air raid of the airport in Kowloon. Consisting of a series of pillboxes, bunkers and trenches constructed in the late 1930s, the defensive line was situated in the mountains in the north of the Kowloon Peninsula to prevent the Japanese from invading from the New Territories. Manned by the British Battalion and Indian regiments, this defensive line was expected to repulse the Japanese invasion or at least resist it for 3 weeks. Unexpectedly, it was breached within 2 days on 10 December. To a great extent, the line represents a painful memory of the war in Hong Kong-the failure of the British Battalion and the Hong Kong Garrison ${ }^{5}$ to safeguard the colonial territory. It is a constant reminder of the serious military and civilian casualties and war crimes resulting from the 18-day fight that ended on 25 December, known as 'Black Christmas', when the Governor-General of Hong Kong surrendered (Lai 1999; Lowry 2011; Cartwright 2020).

On the other hand, the Green Ridge (Fig. 3) in Malaysia was a small yet symbolic victory of the British Battalion against Japanese military aggression. The Green Ridge, one of three peaks in the mountain range in northern Kampar, was one of the sites of the Battle of Kampar, which is considered the fiercest battle of the Malayan campaign (8 Dec 1941 to 31 Jan 1942) (Gilani 2012). The campaign began on the same day as that in Hong Kong, when Japanese troops launched an amphibious invasion on the north-eastern coast and simultaneously crossed the border from Thailand near the western coast, advancing southward along the roads across the Malay Peninsula (Fig. 4). Kampar, located in Perak State and possessing the only trunk roads on the western coast at the time, was an inevitable stop along the route of the Japanese southward offensive. The Battle of Kampar took place on 30 December 1941, in the forested mountain where the British Battalion had built a series of makeshift outposts (ranging from gun emplacements to trenches and mortar pits) to secure vantage points for an ambush. The battle has been hailed as a memorable Allied triumph, partly because the British Battalion and Indian regiments were significantly outnumbered yet suffered few causalities while successfully inflicting heavy casualties on the Japanese army. More particularly, Allied soldiers resisted the attack for 4 days, thwarting the Japanese general's goal of taking over Kampar before the New Year. Regretfully, the defensive positions at Kampar were abandoned on 2 January 1942. Afterwards, when the Japanese troops captured the Malay Peninsula on 31 January, the last Allied forces left Malaya and retreated to Singapore, thus concluding the

\footnotetext{
${ }^{5}$ The Hong Kong Garrison consisted of British battalions, the Royal Artillery, Canadian battalions, Indian forces and the Hong Kong Volunteer Defence Force Cartwright 2020).
} 


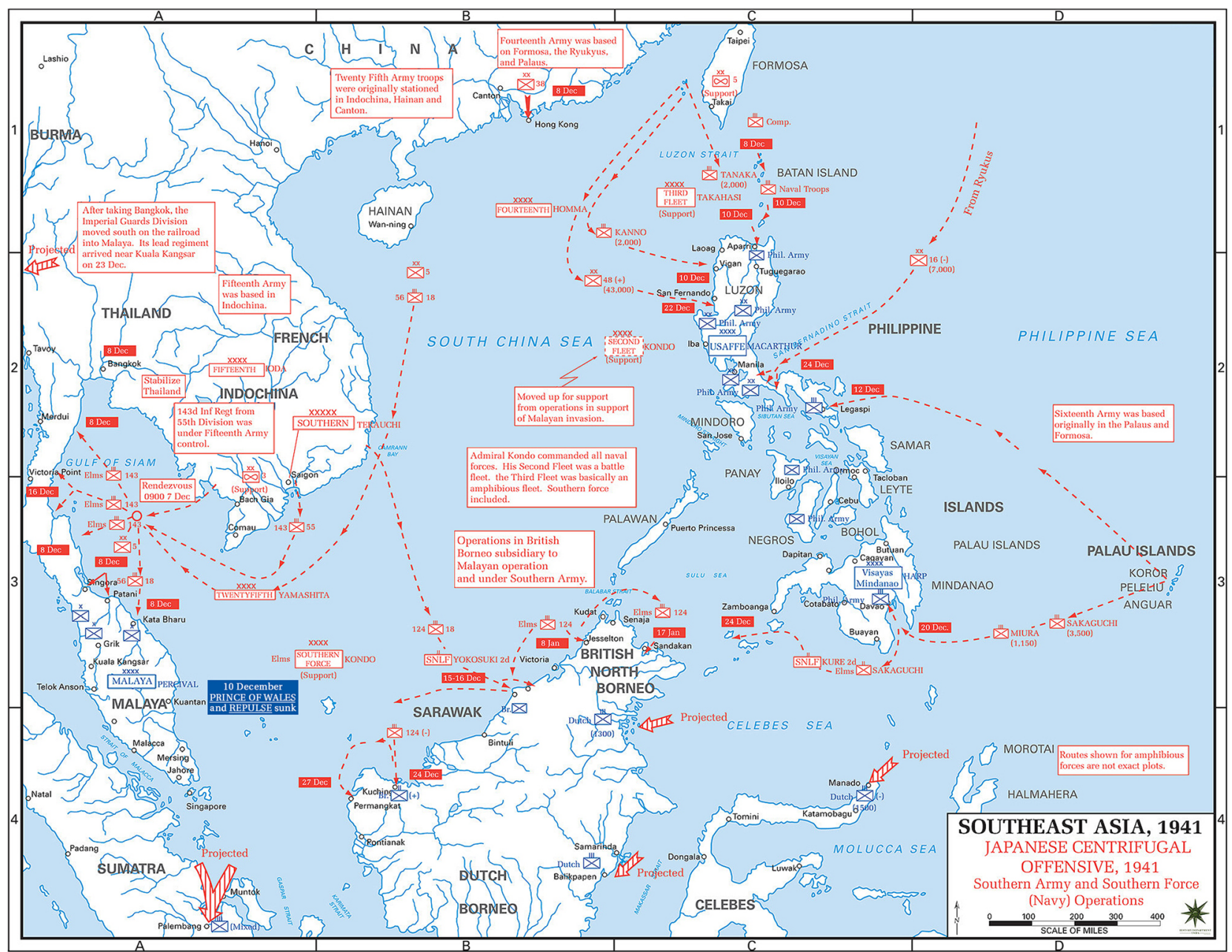

Fig. 1 Map of Japanese offensive in Southeast Asia in 1941. After attacking the Pacific Fleet at Pearl Harbor, the Japanese invaded Hong Kong and Malaysia on 8 December 1941 (Source: public domain image, courtesy of the United States Military Academy Department of History, available at http://www.emersonkent.com/map_archive/japanese_offensive_1941.htm)

Malayan campaign, which is considered to have been a catastrophic defeat of Allied forces (Gilani 2012; Muzaini 2013).

The term 'battlefield' may be misleading in terms of what the two locations look like. Neither of the two is a 'field', which generally suggests flat, open ground; instead, the terrain is quite rough and mountainous and is filled with dense vegetation. Due to the tropical and subtropical climate, both battlefields periodically experience monsoon-like downpours and, consequently, severe mudslides and erosion. These natural processes make it even more challenging to preserve the original state of the sites. The two battlefields are also geographically immense, especially that in Hong Kong, where the fighting spread out extensively. Thus, it is impossible to keep any of the two battlegrounds completely or even mostly intact, considering the changeable nature of the terrain and the battle's wide geographical spread. Technical difficulties and economic practicalities aside, the main battlefield conservation issue focused on here is social and political engagement with the land. In the case of both battlefields, the campaigns to protect this WWII heritage were mainly bottom up and citizen led.

\section{2 'Local' stakeholders and the fight for safeguarding WWII battlefields}

There are three main parties in host nations involved in the conservation of battlefields as transnational heritage: individual and local citizens, academic or research institutions, and the government. While the awareness campaign for protecting the WWII battleground in Malaysia was initiated by a concerned Malaysian citizen, academics and researchers were the dominant figures in drumming up interest and support from the general public for preserving the Hong Kong battlefield.

In Malaysia, protecting the remnants of WWII battles was never firmly on the government's agenda in the last century. The shift in the Perak state government's 


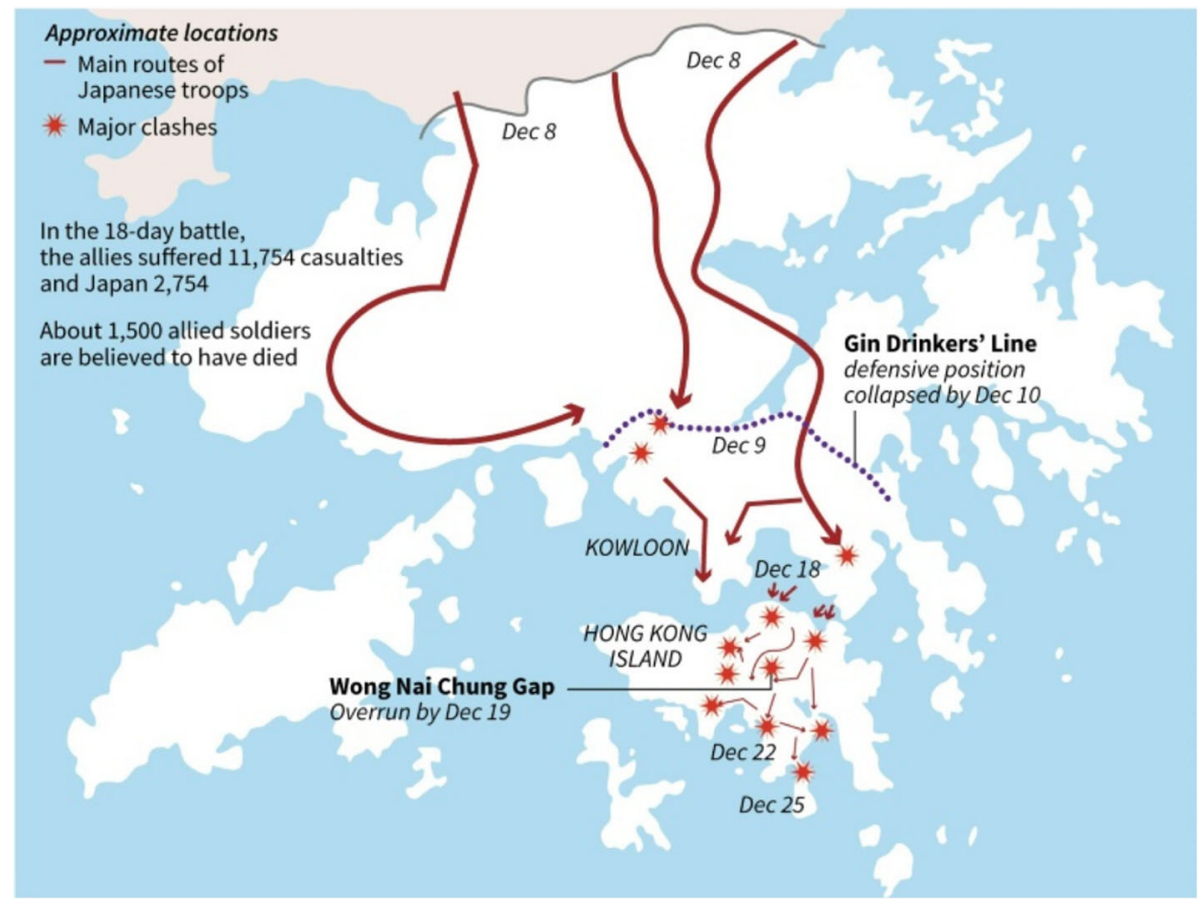

Fig. 2 The Japanese invasion in Hong Kong and the location of the Gin Drinkers' Line (Source: Monro 2018)

attitude towards protecting Green Ridge at the dawn of the 21st century can be attributed mainly to the late activist Chye Kooi Loong, a retired high school teacher who experienced the battle at the age of 12 and formed lifetime friendships with other survivors (Chye 2002). Chye was a long-standing advocate in the political struggle to preserve the remnants of the Battle of Kampar (Muzaini 2013). Having witnessed Thompson Ridge, located to the north of Green Ridge, being turned into a housing development and Cemetery Ridge, to the south, become grossly neglected and then reclaimed by nature and overgrown with plants, he was determined to fight his own battle to protect Green Ridge-the last remaining area of the battlefield (Muzaini 2013).

In the early years, he collected many artefacts from beneath layers of organic mass in the jungle and then restored and donated them to the Department of $\mathrm{Mu}$ seum and Antiquities (DMA) in Kuala Lumpur. Seeing the educational value of his work, the DMA later agreed to republish his book, The British Battalion in the Malayan Campaign 1941-1942 (first published in 1984), in 2002 (Chye 2002). In his foreword, the Director General of the DMA notes that Chye's work 'keep [s] alive the heroism of the British Battalion, and together with the actual battleground, which is still to be seen at Kampar, will always remind us of this important and terrible history in our national history' (Chye 2002, iv). Chye set up memorial plaques and signage on his own to inform locals of the importance of the battleground and prevent the government from erasing its colonial history. He saw British war veterans and their families visiting the ridges and the Taiping War Cemetery where the Commonwealth War Graves Commission interred fallen British soldiers and witnessed Japanese visitors burning incense sticks, openly shedding tears and emotionally engaging with the battleground. Capitalising on these transnational memories of the war and enlisting diplomatic support from the UK and India, he successfully promoted the importance of this 'hallowed ground'-a term used by professionals to describe land that is considered to have attained a sanctified status because of the blood shed over it, which generally disqualifies it from being developed (Byrne 2009; Muzaini 2013).

Later in this campaign, to overcome local resistance and apathy, he changed his tactics to garner community support by highlighting the efforts of local men and women to help the British defence. He strove to change the perception that people had of the Green Ridge battle from being an episode of imperial history to a more accepted part of Malaysian history (Muzaini 2013). Chye emphasised the pivotal role of many Perakians (local Malays) in repelling Japanese troops and helping Allied forces by using their knowledge of the terrain, providing intelligence and supplies, and putting up defences. By shifting the narrative from the imperial to the local, Chye made local people reconsider the importance of the land. In the fight to preserve the land and raise awareness, Chye employed various strategies, ranging 


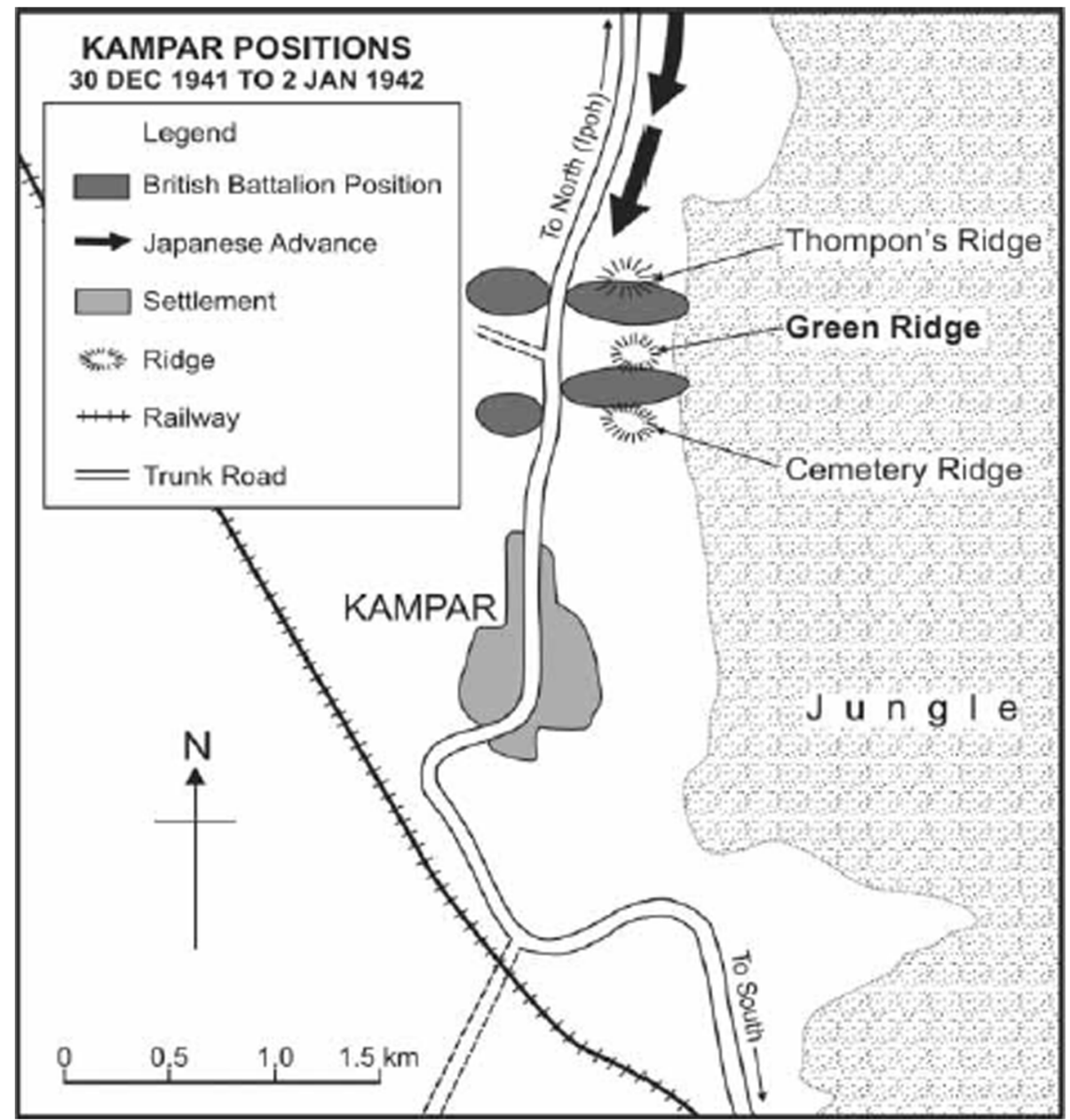

Fig. 3 Green Ridge Battle (Source: Muzaini 2013)

from displaying information on plaques, memorials and signposts and collecting war artefacts to changing locals' perception of the battle site. These efforts eventually paid off. In 2006, the Perak state government agreed to designate Green Ridge as a historic site, although this decision remained subject to the approval of the national heritage authority. Statutory protection was then hindered by negotiation with nearly two hundred landowners to give up their ownership of land on the Green Ridge in exchange for land elsewhere. Local historians and former army officers in Kampar later joined Chye's crusade to protect the remains of the battleground (The Star 2006, 2009, 2010). However, the long process of land expropriation aroused widespread suspicion about whether the state government intended to fulfil its promise. It was an agonisingly long wait before the Green Ridge was officially listed as a national heritage site in 2019 (Muzaini 2013; Bunyan 2019).

In Hong Kong, interest among historians in the history and relics of WWII emerged in the mid-1990s, which coincided with the national survey undertaken in the UK in 1995 to identify, document and conserve tangible and intangible remnants of WWII (Keung and Wordie 1996; Lai et al. 2009; Lowry 2011; Historic England 2017a). Similar to the efforts in Malaysia to conserve WWII heritage, those in Hong Kong have been undertaken by local heroes like Chye but have also been collectively and collaboratively furthered by researchers from educational and professional institutions in Hong Kong (Lai et al. 2009; The Hong Kong Institute of Surveyors 2011). Since the early 2000s, there have been an increasing number of historical studies on the Gin Drinkers' Line and a series of large-scale surveys on the crumbling fortifications, such as trenches and steel-reinforced machine gun pillboxes, in the area (Figs. 5, 6 and 7). These are all part of a strategy to show the local government and people the uniqueness of their history and how they can capitalise on this military heritage. It is hoped that 'with the availability of more and better information, politicians and the Hong Kong public will push for the 


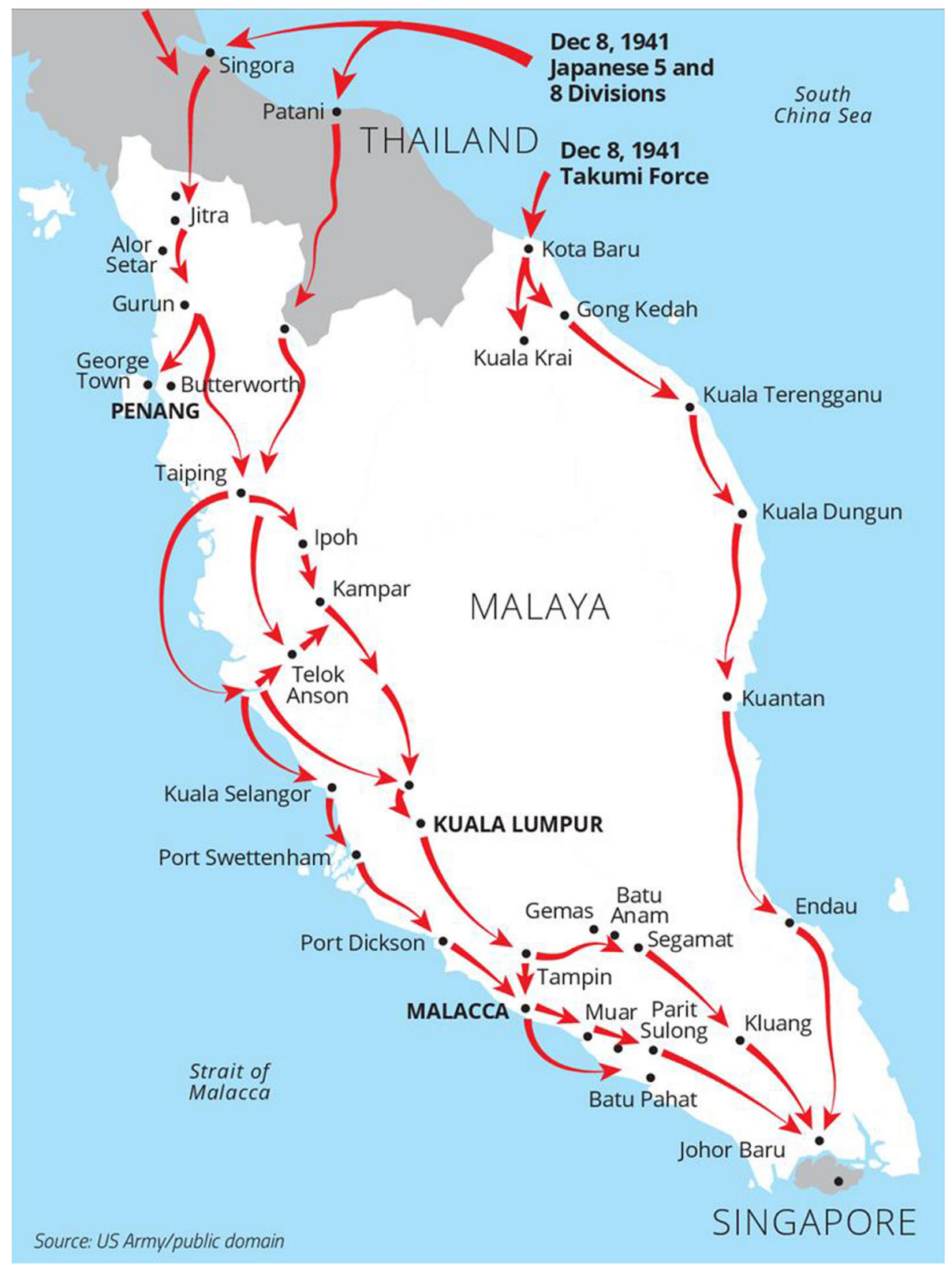

Fig. 4 Japanese invasion routes from Thailand to Malaya and then Singapore (Source: Rouwen Lin, 'Invasion of Malaya: First shot in the Pacific war', The Star, 8 December 2016. Available at: https://www.thestar.com.my/lifestyle/people/2016/12/08/invasion-of-malaya-the-japanese-arrive)

conservation of its Second World War military heritage as part of [Hong Kong's] aspiration to be an international and multicultural city' (Lai et al. 2009, 36).

While well-intentioned individuals and researchers have successfully generated awareness of this urgent need and called for prompt action from the government to protect the Gin Drinkers' Line, disagreement remains regarding what should be prioritised when conserving battlefields. In 2009, Shing Mun Redoubt, a 12-acre underground citadel featuring a network of tunnels, observation posts and pillboxes, was listed as a Grade 2 heritage site. It previously appeared to be the only military structure situated along the line that has been officially ascribed heritage status (Antiquities Advisory Board 2009b). Although the redoubt is clearly 'a major anchor of the line' (Lai et al. 2009, 19), the protection of this major fortification structure has not prevented the fields of the defensive line, stretching over 11 miles, or various military installations within the field from becoming covered in vegetation. In a recent heritage impact assessment commissioned by the Architectural Services Department (Spence Robinson Ltd 2016), minimal references were made to the condition of the pillboxes and trenches along the defensive line. The vast 


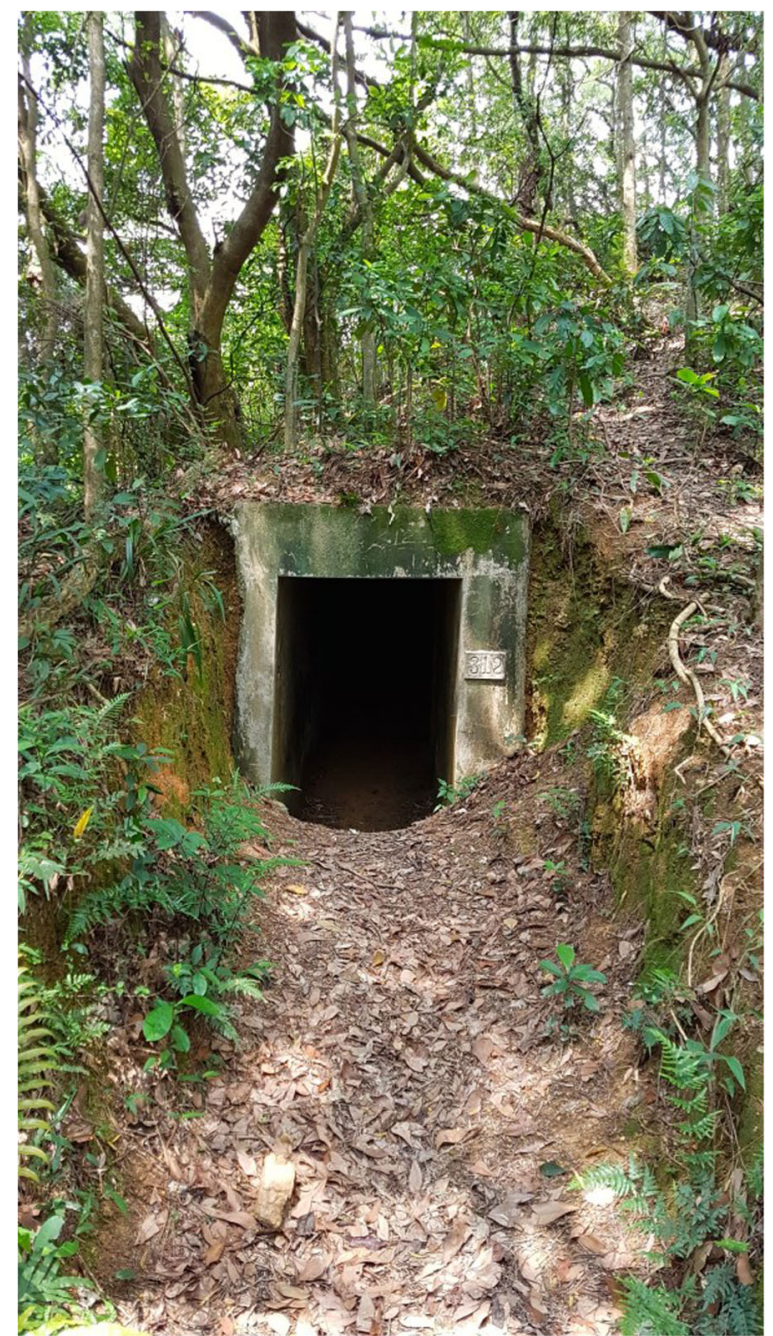

Fig. 5 Tunnel entrance (Source: www.hkoutdooradventures.com) majority of efforts and resources from the government were put towards the renewal and redevelopment of old military barracks and battery (artillery) positions located near urban areas. These areas are more easily accessible to the public. The pillboxes located in mountainous and hilly regions that are overgrown by vegetation appear to be forgotten except by the local hiking enthusiasts and researchers from neighbouring universities who seek them out (Fig. 8). The heritage impact assessment report includes the Gin Drinkers' Line and the Shing Mun Redoubt on the list of important military fortifications in Hong Kong and notes that the two places are 'well-preserved' (Spence Robinson Ltd. 2016, 17). This statement contradicts an assessment conducted by the University of Hong Kong several years ago. A research team from the university carried out an extensive survey of the status of the pillboxes. By observing old aerial photographs, they found a total of 76 pillboxes, 50 of which still exist today. Of those 50, fewer than ten were considered 'well-preserved' (Lai et al. 2009, 16). The pillboxes and trenches have been victims of vandalism, plundering, and scavenging for steel and bricks (Lai et al. 2009). The negligence of military installations located away from urban areas needs to be addressed before more war remnants are vandalised or destroyed.

In Malaysia, much of the credit for saving the Green Ridge was given to a single individual, but most citizens still bear scars left by the war and engage in various activities to commemorate WWII (Cheah 2007). In Hong Kong, the protection of the Gin Drinkers' Line and other remnants associated with the Battle of Hong Kong was vigorously advocated for by research and professional institutions such as the University of Hong Kong and the Hong Kong Institute of Surveyors (The Hong Kong

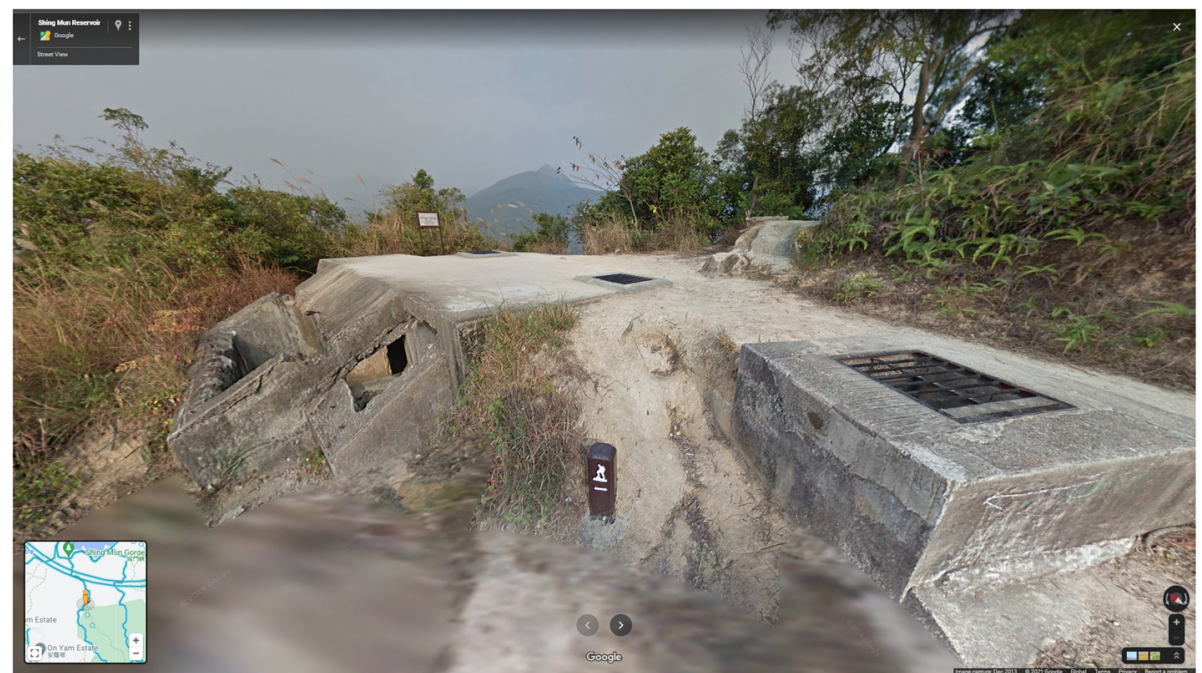

Fig. 6 One of the better-preserved pillboxes along the Gin Drinkers' Line (Source: Google Street View) 


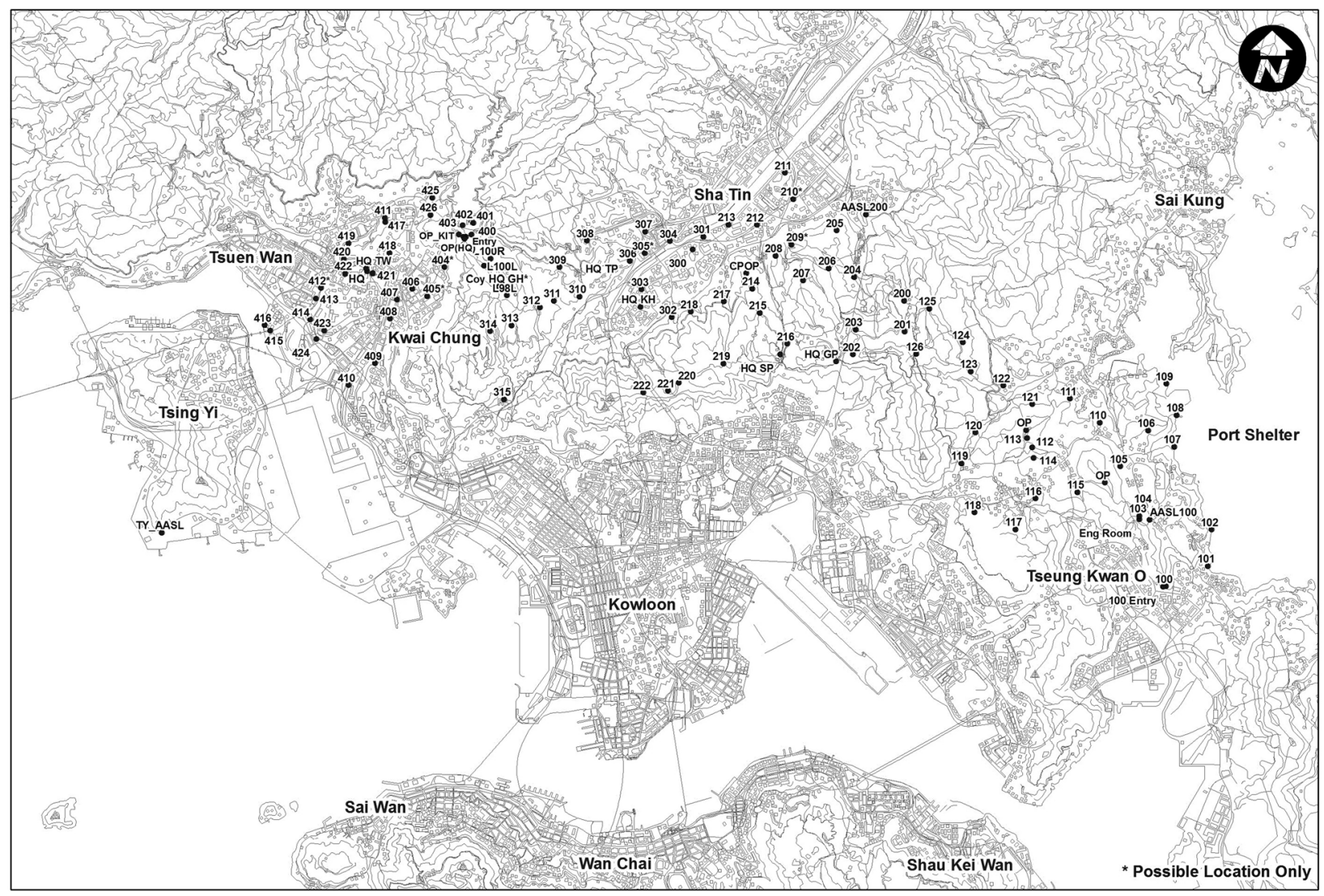

Fig. 7 Location of pillboxes and other structures of the Gin Drinkers' Line based on aerial photography (Source: Lai et al. 2009)

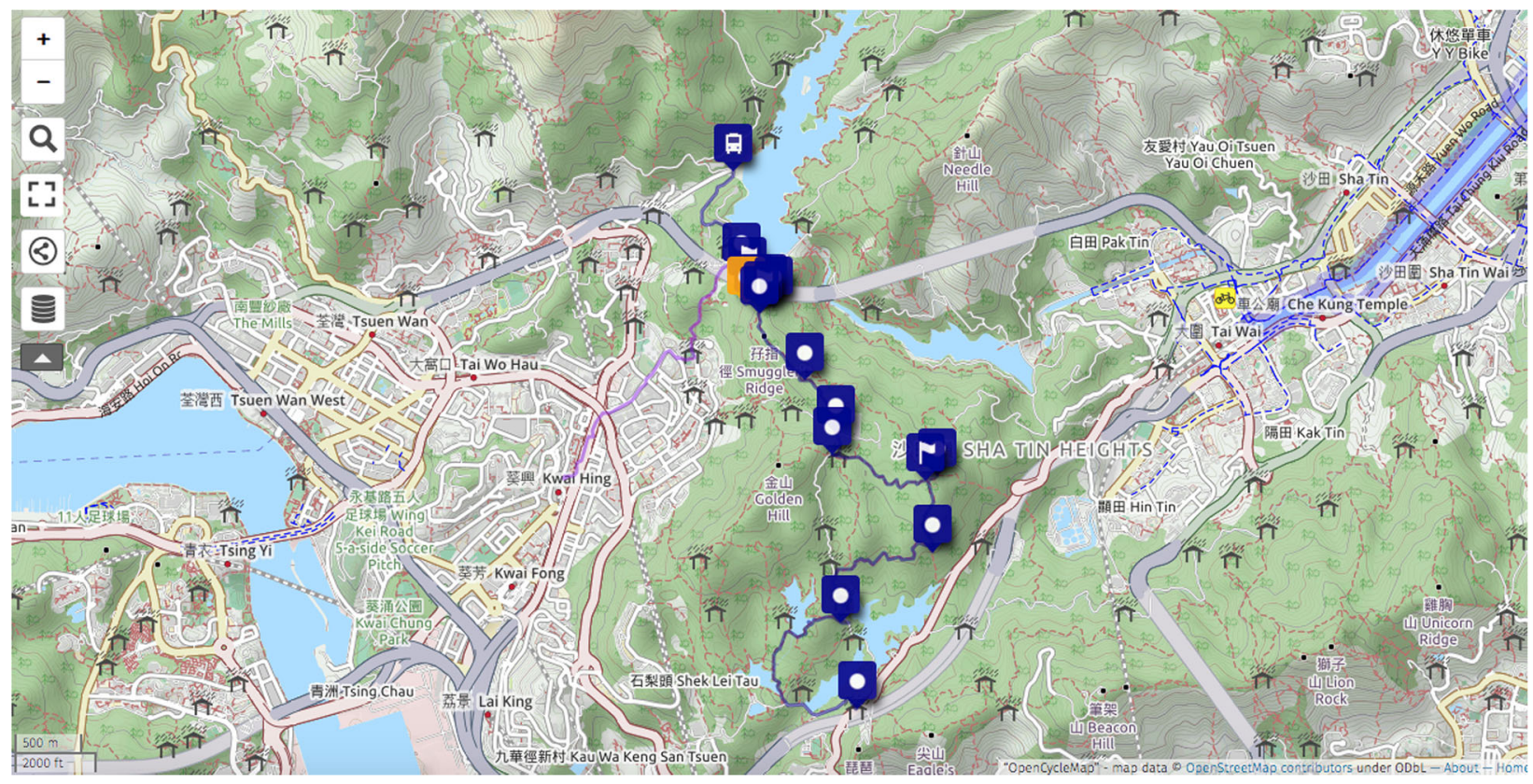

Fig. 8 Section of the Gin Drinkers' Line in the New Territories with hiking information (Source: www.hkoutdooradventures.com) 
Institute of Surveyors 2011; Lee 2012). It should be noted that, in both cases, people from a wide array of nationalities gathered to fight for the preservation of the battlefield for different reasons. The lightning-fast advances of the Japanese army and naval fleet threatened the British Empire and the sovereignty of many nations in the Asia-Pacific region. The combatants who met on the battlefield included Japanese, Koreans, Chinese, Irish, Scots, English, Portuguese, French, Indians (Rajputs and Punjabis), Australians and Canadians (Lai et al. 2009). Many of the soldiers were young, inexperienced and unfamiliar with the terrain, yet they banded together. To make progress in saving these battlegrounds, the Hong Kong and Malaysian governments need to recognise the value of such transnational heritage. If it were not for these foreign soldiers fighting to defend their land from invaders, the sovereignty of the country or even the entire region might look different today. Nonetheless, faced with local activists' campaign for protecting these WWII battlefields, both the Hong Kong and Malaysia governments were originally reluctant to respond to the call.

\section{Reluctance to protect WWII heritage}

This shared reluctance had various causes. The Hong Kong government's disinclination to protect the WWII battlefield generally had more to do with the lack of tangible economic incentives to do so; more importantly, political complications caused concern among the governments of both Hong Kong and Malaysia.

\subsection{Economic challenges}

Although Hong Kong is renowned for its land-hungry development, the Gin Drinkers' Line is situated far from urban areas and faces no immediate threat from property development initiatives. Instead, its remote location poses greater challenges in efforts to preserve the battleground by repurposing the military installations there. Scholars have noted that the cultural significance of these installations remains disputable (Lee 2012; Lee and Lai 2019). It is difficult to justify the battlefield as being historically valuable because it was not associated with a notable military action or renowned victory, and some of the pillboxes never saw any shots fired. The pillboxes' aesthetic value is uncompelling because these defensive structures were erected quickly and economically during wartime and were never meant to be permanent. Nor can their social value necessarily be justified since the battle took place across mountainous areas that have been out of sight and out of mind for urban audiences in Hong Kong. For these reasons, finding a suitable modern function for these military remnants in remote locations would be challenging, but a feasible proposal to generate publicity and sustain their continued existence can be leveraged to enhance their social value (Lee and Lai 2019).

In contrast, land developers placed intense pressure on the local government of Kampar to open up the Green Ridge for development. A local mining factory has already taken over parts of the ridge, and a road running nearby was just widened to meet traffic needs (Muzaini 2013). Compared to the efforts in Hong Kong, the Kampar government's early efforts to curtail development in the area were somewhat limited. Land on the Kowloon Peninsula is much more valuable than that in Kampar. Nevertheless, the Kampar government appeared less willing to support research on and surveys of the defensive outposts constructed by the British during WWII or to protect such structures. Debatably, this is because acknowledging the remnants of WWII as part of the nation's heritage is seen more as a political issue than a social or economic one (Harrison 2010; Saito 2016; Ching 2019).

\subsection{Political complications: the strategic forgetting and indelible memories of the war}

It can be argued that the current relations of Britain and Japan with China and Malaysia may have influenced how the two host nations respond to urgings from local activists and foreign governments to protect these WWII battlefields. The distinctive historical trajectories of Hong Kong and Malaysia in breaking away from the British Empire's colonial procession differ significantly. British colonial rule in Hong Kong and Malaysia ended at different times after the war. Hong Kong was the most popular and last overseas territory of the British Empire, lasting until the end of the 20th century. After being handed over to China in 1997, it entered a 50-year transitional period meant to continue the economic and political systems established during colonial rule while coming under China's administration. While Hong Kong has historically been close to Britain, China's historical hatred towards Japan prevents the easy alliance of the current government and the Britain because their colonial past symbolises a period of national humiliation for China. Conversely, Malaysia achieved complete independence in the early years of the post-war decolonisation surge. The crafting of Malaysia's post-colonial identity as an independent nation-state and that of Hong Kong as an autonomous region within China are ideologically disparate (Cheah 2007; Vickers 2019).

In Malaysia, WWII has long been considered an episode of the country's inglorious past-'the "colonial" war [that should be excluded] from national historiography' (Muzaini 2019, 110). Not long after the Federation of Malaya gained independence and joined the Commonwealth of Nations in 1957, the new government began showing no interest in observing British war 
commemoration rituals (Muzaini 2019). Remembrance ceremonies ceased, and various plaques, markers, and other traces of the two global wars left by the British were deliberately removed. There was a perceived need to erase the British Malays and WWII from the nation's formal remembrance of its past. By the 1980s, to forge and strengthen more assertive diplomatic and economic ties with Japan, the Malaysian government strove to hide or discount the war crimes and atrocities committed by the Japanese while on the offensive (1940-1942) and when Malaysia was under occupation (1942-1945). Muzaini $(2019,110)$ describes this strategic forgetting:

It was thus as if the Japanese had never arrived or that their arrival was not seen as worthy of remark. ... for all intents and purposes, the war may have been perceived as a war between [the British and Japanese] empires where locals did not play a part, and thus as an episode either irrelevant or potentially harmful to post-colonial nation-building efforts.

Cheah $(2007,47)$ describes this selective amnesia as the 'black-out syndrome' of the Malaysian government, which 'is determined to exorcise the ghosts of the war'. However, while the government sanitised the narrative of the Malayan campaign and the subsequent Japanese occupation in a diplomatic tone, the memories of the war remained vivid and alive in the minds of the public.

Cheah $(2007,50)$ describes WWII as a 'divisive issue' between the state and civil society in Malaysia. The atrocities and massacres committed by Japanese troops and the hardships and terror experienced during Japanese occupation still haunt the memories of the general public, especially of older generations. However, the Malaysian government showed a greater inclination to 'forgive and forget' Japanese war crimes to sustain its economic and diplomatic ties with Japan in the post-independence years. The government deliberately pronounced the end of WWII to be a turning point in history that 'awakened the people's national consciousness, and expedited their struggle and march towards self-government and national independence' (Cheah 2007, 48). While British colonial rule in Malaysia might not have left a positive impression on the public's national mentality, the 'Japanese had inspired the people with an anti-colonial spirit' (Cheah 2007, 49).

In Hong Kong, on the contrary, WWII has rarely been given much attention, as the four-year Japanese occupation (1941-1945) was just a short interval in the British Empire's century and a half of colonial rule (18411997). At the end of WWII, it was simply a matter of 'getting back to normal'. The commemoration of the war was observed annually in Hong Kong in the same manner as it was in Britain proper: in well-attended ceremonies led by former British soldiers, prisoners of war (POW) under Japanese occupation, and their families (Vickers 2019) on Remembrance Day (11 November). Resentment against the Japanese was rarely seen in post-war Hong Kong, in part because inciting ethnic or racial hatred went against the accepted norms of twentieth-century Britain, which governed multi-racial Commonwealth countries across the globe, and because Hong Kong, similar to Malaysia, depended on crucial Japanese investments and trade. In the run-up to the 1997 handover of Hong Kong, the British colonial government's most high-profile initiative to commemorate the war was the conversion of the Lei Yu Mun Barracks into the Hong Kong Museum of Coastal Defence ${ }^{6}$ proposed in 1993 (Henderson 2001; Cartwright 2020). The return of Hong Kong to China in 1997 ultimately changed how the history of region would be remembered and how WWII would be commemorated. As Vickers $(2019,146)$ notes:

The [British] colonial era symbolizes China's humiliation; ... [which] evokes no interest, only embarrassment. In formulating an officially sanctioned position on the local past, the spotlight has therefore been trained overwhelmingly on Hong Kong's relationship with China. Aspects of the experience of Japanese invasion and occupation irrelevant to this [pan-Chinese nationalism] theme, such as the battle for Hong Kong itself (pitching mainly British troops against the Japanese) thus tend to be downplayed.

The commemoration and remembrance of WWII in Hong Kong was gradually woven into the narrative of China's WWII history, obscuring the presence of the British colonial government. The public holiday in the British Empire that previously celebrated the liberation of Hong Kong from Japan (Liberation Day, the last Monday in August) was abolished and replaced with a celebration of the retrocession of Hong Kong to China (1 July). The observance of Britain's Remembrance Day (11 November) in Hong Kong ceased, and the commemoration of the war dead was moved to the Double Ninth Festival (9 November on the Chinese lunar calendar) - the day that Chinese in Hong Kong customarily

${ }^{6}$ Lei Yu Mun Barracks held great defensive significance to repulse the Japanese invasion during WWII. The British colonial government proposed to convert the barracks into a museum in 1993 to dedicate to the Royal Hong Kong Regiment (The Volunteers), the local-raised militia that had defended the overseas territory for over a century. The Hong Kong Museum of Coastal Defence was completed in 2000-three years after the handover of Hong Kong to China. In 2009, several structures within the Museum were listed as Grade 1 and Grade II historic buildings (Antiquities Advisory Board 2009a). 
visit their ancestral graves and honoured the dead. The Hong Kong Museum of Coastal Defence, completed in 2000, also now shows 'a wholesale revision of its intended focus' (Lai et al. 2009, 18). The museum emphasises the site as a defensive stronghold in precolonial years, i.e., during the Ming and Qing dynasties. As physical remnants of WWII, the Lei Yu Mun Barracks compound was incorporated into the story of the Japanese invasion in southern China, portraying the Chinese in Hong Kong as patriots fighting the Japanese and painting a picture of Chinese unity (Vickers 2019). While 'pan-Chinese nationalism' (Vickers 2019, 160) may overwrite the 'local', and particularly 'colonial', dimension of the Battle of Hong Kong, local residents and researchers have strived to remember this global armed conflict in the recent past and protect the WWII military installations left by the British (Lai et al. 2009). The heightened societal expectations of offering statutory protection to WWII-related sites eventually paid off. By 2009, the Antiquities Advisory Board (the heritage authority of the Government of Hong Kong) conducted detailed surveys on 1444 historic buildings (2002-2004), including a range of military sites such as the Lei Yu Mun Barracks and the Shing Mun Redoubt, in its heritage inventory (Antiquities Advisory Board 2021).

\subsection{International pressure and local persuasion}

The political ideology of countries and diplomatic relations between them-both in the past and the presentpose challenges for protecting WWII battlefields as transnational heritage sites. As Price (2005) argues in his essay on 'orphan heritage', a paradox is commonly seen between heritage ownership (all the soldiers and the nations they represented) and location ownership. These conflicts of interest can become increasingly antagonistic if the owners of the physical location unknowingly or uncaringly destroy or neglect the battle site, refusing to enact statutory management policies or protective legislation. The Malaysian government chose to forget its colonial history and instead focus on constructing a new, post-colonial nationhood. However, as Muzaini (2013, 396) explains in his article on the vernacular memory and the scale politics associated with the preservation of the Green Ridge, 'the forgetting of the war forms the boundaries around what is seen as salient for citizens to remember towards forging a Malaysian shared identity'. In the face of this resistance to remembering the past, British High Commissioner Vicki Treadell gave an impassioned commemoration speech on Remembrance Sunday in November 2018, reminding British and Malaysian diplomats of the sacrifices that so many people made in defending their countries and safeguarding their freedoms. She remarked (full speech in Treadell 2018):
Here in Malaysia, 7,292 headstones stand as sentinels to further sacrifice at Commonwealth War Graves across 35 locations. If one walks between the graves, you will find men of different races. From Indians to Gurkhas, Canadians, Australians, Brits and Kiwis. Brothers in arms. Brothers in death.

Her speech carried a sense of urgency, pleading with lawmakers to remember the past and not forget the thallowed ground' binding the two nations together. At the behest of local grassroots initiatives in Malaysia, people from the UK and other countries were 'persuaded to write to the Perak state or via the media for the site to be preserved' (Muzaini 2013, 399). This pressure placed on politicians in Malaysia helped them better understand the need to manage the country's colonial past. More importantly, local historians of the Battle of Kampar and various stakeholders in the UK, India, and Malaysia voiced their discontent with the threats facing the Green Ridge and the lack of government action to prevent the area's development.

The decades-long campaign slowly persuaded the Malaysian government and citizens to make efforts to conserve and commemorate WWII. In May 2019, the Kampar government officially issued its decision to register the Green Ridge as a heritage site and announced that the National Heritage Department and the federal government were expected to confirm their decision. Meanwhile, the Indian government proposed providing funding to erect a memorial to commemorate some 1300 British and Indian Allied soldiers who effectively halted the progress of more than 4000 Japanese troops for 4 days, delaying their advance southwards towards Singapore and shattering the confidence of the Japanese general (Bunyan 2019). Facing domestic and international pressure, the Malaysian government has managed such criticism diplomatically, striking a balance between protecting the memory of the country's colonial past and asserting its current independence and identity.

\section{Battlefields as transnational heritage and international affairs}

While there was shared reluctance between the Hong Kong and Malaysia governments, this reluctance stemmed from very disparate post-independent ideologies of each government. However, in both cases, there was an apparent disjunction between society's efforts to remember the war and the political desire to forget it. Why did local citizens feel so differently from politicians about the 'orphan heritage' in their countries? Additionally, safeguarding the battlegrounds of global wars entails bilateral or multilateral agreements and negotiations to achieve consensus. What international efforts have been, or could be, made to prevent or settle disputes over 
orphan heritage? Finally, what do the successes of citizen-led initiatives in Hong Kong and Malaysia to protect 'orphaned' battlefields contribute to our understanding of the transnational value of WWII heritage in Asia?

\subsection{Adoption of orphaned battlefields}

Due to the geographical spread and unprecedented scale of the war, WWII battlefields have invariably suffered neglect and been threatened by land development. General disregard and apathy may stem only partly from the economic impracticality of preservation efforts, but they also largely result from political complications. After the war, Hong Kong continued to commemorate the war in the best traditions of British practice. While Britain was preoccupied with the reconstruction of London and major cities devastated by the Blitz (German mass air raids), the battlefields across the forested, mountainous terrain in Hong Kong did not necessitate that the colonial government act with urgency to address them. In the run-up to the handover of the region, the colonial government realised the need to protect WWII heritage in Hong Kong to pay tribute to local combatants by converting the military barracks into a museum. Although it dawned late, this realisation in the 1990s resulted in a state-led commemorative initiative that perfectly coincided with the rise in global interest in sites of human death and suffering in both the research fields and industries of heritage and tourism (Hartmann 2014; Ashworth and Isaac 2015). Following the handover, the Hong Kong Museum of Coastal Defence, as a war heritage site imbued with additional value through interpretation, became a mouthpiece for the new ruling government, weaving the retroceded territory of Hong Kong into a narrative of pan-Chinese nationalism and anti-Japan antagonism while de-emphasising British colonial rule and the WWII battle fight against the Japanese troops. Nonetheless, for the civil society in Hong Kong, cutting off the entire century and a half of close ties with the British could not just happen overnight, and the war could not be easily forgotten either. Similarly, strong colonial ties and the indelible imprint of the war were firmly lodged in the public consciousness of Malaysian citizens. Although the new political regime quickly eradicated traces of British colonial rule and war commemoration traditions and carefully sanitised the narrative of the Japanese invasion and the country's subsequent occupation, civil society could forgive these trespasses but could not forget about the war.

Living memories of WWII are kept alive in historical writings, school textbooks, museum exhibitions, documentaries, films, war tourism, dedicated websites, blogs and more, all of which play an essential role in arousing societal interest in remembering the war. Even though a large part of these efforts concern the European theatre and quite a few of them represent grand historical narratives constructed by governmental authorities, citizenled commemoration activities continue to prevail and proliferate in Asia. Battlefield pilgrimages in Hong Kong and Malaysia began as an informal form of commemoration led by affected stakeholders: as excursions on trips of British and Indian visitors to the graves in local cemeteries; as an additional ritual in the annual commemoration events on Remembrance Day; and as emotionally charged journeys for Japanese tourists seeking to be closer to the locations where their loved ones died (Price 2005; Muzaini 2013; Vickers 2019). The sentiment that impels international visitors to make the journey to WWII battlefields resonates widely with local memories of the Battle of Hong Kong and the Malayan campaign. As the locus of bloodshed, battlefields become meaningful places to commemorate war deaths and a powerful reminder of the destruction and atrocity of war. Personal interest in and citizen-led initiatives for protecting the WWII battlefields in Hong Kong and Malaysia emerged in the late 1990s-coincident with the rise of heritage and tourism studies on 'dark' heritage sites. The legalised protection of currently empty historic battlefields in the 1990s in Britain may have inspired academics and researchers in Hong Kong to conduct historical research and geological surveys on their own WWII battlefields (Lowry 2011), but the indelible memories of the war effectively stirred grassroots movements to campaign for the local and transnational value of the battlefields in both Hong Kong and Malaysia. These efforts were driven by the compassion and benevolence of individuals, historians, academics and professionals who had no direct relationship with these 'orphaned' battlefields but adopted them as their heritage.

\subsection{Limited intervention of international organisations}

Following the increased interest in warfare archaeology and the protection of 'historic battlefields' in the 1990s, international endeavours to address battlefield conservation led to the original draft of the Vimy Declaration for the Conservation of Battlefield Terrain in 2000 (Carman and Carman 2009; Schofield 2009). The Vimy Declaration came about because of the growing need to resolve discrepancies in conservation regarding the protection of land not defined in international guidelines on heritage protection, such as the Venice Charter (1964) and the Florence Charter (1982). Neither of these two documents mentioned conservation approaches to land that has seen warfare. Thus, a new multidisciplinary group of academics, conservation specialists, ecologists, landscape architects and many more came together in a common call-to-arms of all who were concerned about the protection of battlefields (Bull and Panton 2000). This group spearheaded the drafting effort, addressed the need for a 
new charter and issued the first draft of the Vimy Declaration in 2000.

As a site where atrocities occurred, a battlefield is not merely a location where a historical event has unfolded; it is also a place where some stakeholders affected by the war commemorate their loved ones and a place to which they form a personal attachment. Battlefields are emotionally charged cultural landscapes, as articulated in the most recent draft of the Vimy Declaration (Schofield 2009, 1):

At sites where authentic battlefield terrain has been preserved, such as Vimy Ridge or Vicksburg, the visitor stands in a trench, or at the edge of a shell hole or crater, or deep inside subterranean tunnels, and there is an emotional sense of place, of intersecting the lives of the soldiers. Such locations offer a reaffirmation of personal ties, a way of remembering, and of exploring individual and collective identities.

From this short description, it is understood that the experience of visiting a battlefield is emotional, even though a preserved battlefield inevitably looks quite different today than it did long ago during the war. The Vimy Ridge in the Nord-Pas-de-Calais region of France is significant for Canadians because it holds immense transnational heritage value. It is where the Canadian Military Corps fought together for the first time and is seen as the birthplace of a distinct Canadian identity (Bull and Panton 2000). Unfortunately, the Vimy Declaration has not progressed further than draft form. The recently published ICOFORT Charter on Fortifications and Military Heritage: Guidelines for Protection, Conservation and Interpretation (2018) has attempted to fill the gap left by the Venice Charter (1964) and Florence Charter (1982). Nonetheless, focusing primarily on fortifications, the ICOFORT Charter makes only passing mention of battlefields in its definition of 'military cultural landscapes' (ICOFORT 2018, 1). The question of whether the ICOFORT Charter will significant contribute to how WWII battlefields are conceptualised and protected in the coming decades is yet to be answered.

While the Vimy Declaration and the ICOFORT Charter represent international efforts to lay down principles and provide guidance on protecting battlefields, international organisations have continually avoided intervening in or mediating transnational disputes over battlefields. The extent to which an international organisation such as UNESCO can exercise its power to protect sacred battlegrounds is very limited. When according heritage status to a battlefield may potentially drive a wedge between nations, UNESCO opposes the nomination. The UNESCO advisory board, ICOMOS, rejected the nomination of 19 important WWI sites in
Flanders precisely to avoid controversy and deter historical resentment (Bradshaw 2018). Many more battle sites, such as Like Gallipoli and Dardanelles, remain on the tentative list, as UNESCO continues to debate how best to manage such war heritage (WHC 2014).

\subsection{WWII transnational heritage in Asia}

The reluctance of the governments in Hong Kong and Malaysia to commemorate the war is echoed elsewhere in Asia. However, the reasons that a country may avoid war commemoration activities are very closely linked to that country's distinct course in history-its involvement in the war and, more critically, its colonial and postcolonial past. The involvement of Asian countries in WWII could be ascribed to the declaration of war by the UK and the US, the imperial powers in the region at that time, against Japan. While the Japanese invasion and occupation inflicted casualties and cruelties, it effectively terminated European and US colonial control in the region and consequently paved the way for the independence of their overseas territories-as observed in Malaysia.

As the major aggressor in the Asia-Pacific War, Japan also chose to forget about its humiliating defeat and alienated itself from other Asian countries after the war. As a victim of the war, it has arguably been the first and most dedicated country in the region in commemorating the war, for example, by erecting memorials and holding ceremonies in the cities struck by nuclear bombs, Nagasaki and Hiroshima. These war memorials serve as markers for commemoration as well as tokens of subsequent peace-making efforts (Kishimoto 2004; Cooper 2007). However, for the Japanese, the commemoration of WWII has largely been conducted within the country, rarely abroad. Battlefield pilgrimages to other countries are undertaken privately and discreetly by affected stakeholders and has rarely appealed to the general public. For most Japanese, the war is rather a source of shame, and their presence as tourists at former battlefields may fuel resentment (Blackburn 2016). Unlike visits to war memorials within their own country, visiting battlefields abroad remains controversial and might present risks if Japan were to lay claim to the joint ownership of such transnational heritage.

While Japan's economic success in the 1980s prompted most government authorities in the region to respond diplomatically and establish alliances with the country-temporarily and diplomatically forgetting about WWII-Singapore is an exception and has actively commemorated the war. Following its independence in 1967, Singapore has conscientiously received veterans, prisoners of war, and the families of fallen combatants from abroad on battlefield pilgrimages, using this as a tool for economic development since the late 1970s 
(Muzaini 2006; Blackburn 2016). By the 1990s, there was a noticeable change in the mindset and strategy of the state in forging its national identity by 'localising' the global war (Muzaini and Yeoh 2005). Thus, the narratives shared about WWII emphasised the locals who participated in defending Singapore, for instance, at the Battle of Pasir Panjang. This narrative highlighted the need to remember Singapore's war heroes and the fact that the battles were actually fought on their soil even though they were waged in the name of the British Empire (Muzaini 2006). Thus, the 'locality' of WWII was foregrounded, and its 'globality' was brushed aside. In a sense, this was also the strategy that Chye adopted later in his campaign to overcome apathy and win the support of locals by highlighting the involvement of Malaysians in the war in the hopes of changing the perception of the Battle of Kampar and the Malayan Campaign (Muzaini 2013). By contextualising WWII within the localities and societies of Singapore and Malaysia, the global war that was previously considered an imperial war and irrelevant to local societies was recast as a local war. The emphasis on local societies' involvement in the global war essentially accentuates the value of WWII battlefields as transnational heritage sites.

For the Chinese, the Japanese occupation (1931-1945) not only left an indelible imprint on their memories but also prompted an earnest desire to commemorate the war. China is arguably one of the most prominent countries in Asia in commemorating the war. There has been a shift in the country's narratives of the war-from being a victor to being a victim. Following the establishment of the People's Republic of China in 1949, the narrative of the war placed much of its emphasis on the Chinese Communist Party's triumph in the Second Sino-Japanese War instead of provoking antagonism against the Japanese. After the economic reform and opening-up beginning in 1978, official Chinese narratives began to highlight the barbarism and cruelty of Japanese invaders and the brave resistance and heroic sacrifice of Chinese revolutionaries (Coble 2007). As patriotic education was widely promoted across the country in the early 1990s, memorials were also erected, one after another, in major cities to mark the historical events of the war. Examples include the following: the September 18th Memorial Museum in Shenyang signifies the first point of entry of Japanese occupation in Manchuria in 1931; the Memorial Hall of the Anti-Japanese War in Beijing marks the outbreak of the Second Sino-Japan War in 1937; the Exhibition Hall of the Crime Evidence of Japanese No. 731 Troop in Harbin condemns Japan's mass killing of Chinese residents by deploying biological weapons; and the Memorial Hall of the Victims of the Nanjing Massacre became the official site of commemoration on National Memorial Day on 13 December, the day when Japanese troops captured the city in 1937. This discourse on victimhood helps China promote unity and forge its national identity by commemorating the suffering, violence and casualties inflicted by Japanese aggression (Denton 2014; Frost et al. 2019). Certainly, these places and acts of state-led commemoration raise awareness of the cost of the war in terms of death and suffering, but the extent to which the provocation of interstate antagonism can contribute to our appreciation of war-related sites as transitional heritage remains unclear.

For most Asian countries, the history of WWII in their territory is inseparable from their colonial past. The complexity of this history often led to states in these regions following different trajectories in remembering WWII and, consequently, to disparate paradigms for dealing with this difficult heritage (Blackburn 2010). It is difficult, if not impossible, to generalise or classify how countries in the Asian theatre of WWII have taken up particular behavioural codes to commemorate or obliterate traces of the war. The general public in South Korea, for example, shares anti-Japanese sentiment with China, but the state government has shown ambivalence towards the history and legacy of the Japanese occupation (1910-1945), sharing conflicting interpretations of the war both across different presidencies and under the same president (Lee 2018). Political relations between these countries are fleeting and transitory in nature. Interstate trade may demand diplomatic manoeuvring to forge alliances with traditional rivals. Similar to Hong Kong and Malaysia, both China and South Korea have temporarily re-cast their war memories to build diplomatic relations with Japan at various points in time (Frost et al. 2019; Huang and Lee 2020). On this account, the success of citizen-led initiatives to protect orphaned battlefields in Hong Kong and Malaysia points to the importance of public support for an unbiased and accurate representation of history along with responsible leadership by the local government. With a shared understanding and a unanimous consensus on the significance of WWII battlefields for humanity, it has been recognised that battlefields hold the potential to 'pacify' the bitter resentment that exists between former enemies that now have to reposition themselves as part of a new global order (Daugbjerg 2009; Chappell 2018).

\section{Conclusion}

Battlefield conservation is still considered to be in its infancy, with professionals continuing to learn how to best protect and present the land to the public. The range in size, complexity and level of natural disturbance at each site requires creative thinking in managing such historical assets. Protecting land within political boundaries that has a direct tie to strong nationalist agendas is easy to do, but this task becomes much more difficult when 
dealing with transnational heritage. The massive loss of humanity during both world wars left much more behind than just physical remains on a battle-scarred land; there are also very deep ties between how today's citizens view their relationship with the deceased and the land. Today, visitors to these sacred sites are often descendants of the people who fought there, and this strong personal tie may potentially inspire fictitious accounts of the past.

Forming collaborative international relations is essential for governments to set aside the land and preserve it from commercial land development. The temptation to build on such land for quick monetary gain is hard to circumvent. Many acres of priceless 'hallowed ground' have fallen victim to the blades of bulldozers and excavators. As seen in both Hong Kong and Malaysia, in the absence of government work on battlefield conservation, many individuals and non-profit organisations have stepped in to fill the gap. Regardless of whether the Battle of Hong Kong represents a bitter defeat or the Battle of Kampar symbolises a notable victory, individuals in Malaysia and Hong Kong have taken the burden up themselves, facing overwhelming odds in seeking support from the local community to preserve these areas. They realise the need to remember all aspects of history-both the good parts and those that are less attractive, such as colonial occupation.

Unfortunately, we live in an imperfect world that has suffered from the catastrophic effects of violence and war since time immemorial. Landscapes and terrain across the globe have been marred by past and present armed conflicts. Countless millions of people have perished horrible and tragic deaths. It is the difficult past that is most uncomfortable to talk about. Many people wish to forget certain parts of history, whether it be the Japanese occupation in China, the Civil War in the US, or the colonial occupation of Malaysia. By avoiding the indulgence of the selective memory of past events, nations can develop a fuller, more mature view of their history, thus leading to a better future. Former enemies can be reconciled at the place of conflict; commemorations can take place and speeches made, and the public can be educated on the horrors of war and how we should go to any length to avoid it. Many nations in Asia can learn from the experience and practice of other developed countries with regard to heritage conservation. This paper aims to stimulate further studies on the subject, since the scope of this research is limited to only two sites. There are countless battlefields that are being forgotten and need recognition as heritage sites that are vital to the identity of the nations involved. Without these sites, we will be left with an incomplete picture of history and patchy stories of valour and heroism.

\section{Acknowledgements}

The authors would like to thank Dr. John Schofield for his clarification on the Vimy Declaration and the ICOFORT Charter and Professor Lawrence Lai from the University of Hong Kong for the provision of photos and visual aids. Thanks are also due to the two anonymous reviewers and Prof Plácido González Martínez, the executive editor of Built Heritage, for their very constructive feedback and helpful comments.

\section{Authors' contributions}

Jesse DiMeolo contributed the original idea of the comparative study and conducted the initial research on the two case studies, the development of Vimy Declaration and the role of international organizations in protecting battlefields. Yi-Wen Wang framed the overall structure and the argument of the paper, elaborated the theoretical underpinning and the historical background of the two battlefields, and related the two case studies to the existing body of literature on battlefield conservation. Gao Du contributed to the discussion that positions the findings of the comparative study in the existing studies on WWII heritage in Asia. All authors read and approved the final manuscript.

\section{Funding}

This work was supported by Xi'an Jiaotong-Liverpool University under the Research Development Fund and the Postgraduate Research Scholarship (RDF-16-01-22).

Availability of data and materials

Not applicable.

\section{Declaration}

\section{Competing interests}

The authors declare that they have no competing interests.

\section{Author details}

${ }^{1}$ Department of Urban Planning \& Design, Xi'an Jiaotong-Liverpool University, 111 Ren'ai Road, Dushu Lake Higher Education Town, Suzhou Industrial Park, Suzhou 215123, Jiangsu Province, China. ${ }^{2}$ Planning and Development Services Department, The City of College Station, 4300 Milam Street, Bryan, TX 77801, USA. ${ }^{3}$ Department of Sociology, Social Policy and Criminology, University of Liverpool, based at Department of Urban Planning \& Design, Xi'an Jiaotong-Liverpool University, Suzhou, China.

Received: 24 October 2019 Accepted: 20 June 2021

Published online: 27 July 2021

\section{References}

Antiquities Advisory Board. 2009a. Historic Building Appraisal No.82, 93, 113, 114, 165, 178, 201, 227, 288, 354, 371, 375-Old Lei Yue Mun Barracks, Block 3, 5, 7, $10,17,18,20,21,25,31,32,33,343$. Hong Kong: Antiquities Advisory Board. http://www.aab.gov.hk/en/historicbuilding.php.

Antiquities Advisory Board. 2009b. Historic Building Appraisal No.503_Shing Mun Redoubt. Hong Kong: Antiquities Advisory Board. http://www.aab.gov.hk/en/ historicbuilding.php.

Antiquities Advisory Board. 2021. List of the 1,444 Historic Buildings with Assessment Results (as at 11 March 2021). Hong Kong: Antiquities Advisory Board. http://www.aab.gov.hk/form/AAB-SM-chi.pdf.

Ashworth, G.J., and Rami K. Isaac. 2015. "Have We Illuminated the Dark? Shifting Perspectives on 'Dark' Tourism." Tourism Recreation Research 40 (3): 316-325. https://doi.org/10.1080/02508281.2015.1075726.

Banks, lain, and Tony Pollard. 2011. "Protecting a Bloodstained History: Battlefield Conservation in Scotland." Journal of Conflict Archaeology 6 (2): 124-145. https://doi.org/10.1179/157407811X13027741134148.

Bernstein, Seth. 2015. "Remembering War, Remaining Soviet: Digital Commemoration of World War II in Putin's Russia." Memory Studies 9 (4): 422-436.

Blackburn, Kevin. 2010. "War Memory and Nation-Building in South East Asia." South East Asia Research 18 (1): 5-31. https://doi.org/10.5367/00000001 0790959857.

Blackburn, Kevin. 2016. "The Ghosts of Changi: Captivity and Pilgrimage in Singapore." In Battlefield Events: Landscape, Commemoration and Heritage, 
edited by Keir Reeves, Geoffrey Bird, Laura James, Birger Stichelbaut and Jean Bourgeois, 144-163. Abingdon: Routledge.

Bradshaw, Lisa. 2018. "UNESCO Advisory Board Rejects First World War as Heritage." Accessed 3 June 2019. http://www.flanderstoday.eu/unesco-deba te-war-heritage-deciding-flanders-fields-recognition

Bull, Natalie, and David Panton. 2000. "Drafting the Vimy Charter for Conservation of Battlefield Terrain." APT Bulletin 31 (4): 5-11. https://doi.org/10.2307/1504 671.

Bunyan, John. 2019. "Kampar Green Ridge, Site of WW2 Clash, to Finally Be Gazetted as Historical Spot." Malay Mail, 06 may 2019. Accessed 20 Jan 2021. https://www.malaymail.com/news/malaysia/2019/05/06/kampar-green-ridgesite-of-ww2-clash-to-finally-be-gazetted-as-historical-s/1750210

Byrne, J. Peter. 2009. "Hallowed Ground: The Gettysburg Battlefield in Historic Preservation Law." Tulane Environmental Law Journal: 203-269.

Campi, J. 2019. "Civil War Trust Eclipses 30,000 Acre Milestone." Accessed 20 May 2019. https://www.battlefields.org/news/civil-war-trust-eclipses-30000-acremilestone

Carman, John, and Patricia Carman. 2009. "The Intangible Presence: Investigating Battlefields." In Heritage Studies: Methods and Approaches, edited Marie Louise, Stig Sørensen, and John Carman, 292-315. London: Routledge.

Cartwright, John. 2020. "The Defence of Hong Kong: Shing Mun Redoubt and the Gin Drinker's Line." Accessed 16 Mar 2020. http://www.hksw.org/Shing\%2 OMun.htm\#_ftnref1

Chappell, Jonathan. 2018. "Some Corner of a Chinese Field: The Politics of Remembering Foreign Veterans of the Taiping Civil War." Modern Asian Studies 52 (4): 1134-1171. https://doi.org/10.1017/S0026749X16000986.

Cheah, Boon Kheng. 2007. "The 'Black-out' Syndrome and the Ghosts of World War II: The War as a 'Divisive Issue' in Malaysia." In Legacies of World War II in South and East Asia, edited by David W. H. Koh, 47-59. Singapore: Institute of Southeast Asian Studies.

Ching, Leo T.S. 2019. Anti-Japan: The Politics of Sentiment in Postcolonial East Asia. Durham: Duke University Press Books.

Chye, Kooi Loong. 2002. The British Battalion in the Malayan Campaign 19411942. Kuala Lumpur: Documentation and Publication Unit, Department of Museum and Antiquities.

Coble, Parks M. 2007. "China's 'New Remembering' of the Anti-Japanese War of Resistance, 1937-1945." The China Quarterly, no. 190: 394-410. https://doi. org/10.1017/S0305741007001257.

Cooper, Malcolm. 2007. "Post-colonial Representations of Japanese Military Heritage: Political and Social Aspects of Battlefield Tourism in the Pacific and East Asia." In Battlefield Tourism: History, Place and Interpretation, edited by Chris Ryan, 73-86. Oxford: Elsevier. https://doi.org/10.1016/B978-0-08-0453620.50012-9.

Danilova, Nataliya. 2015. The Politics of War Commemoration in the UK and Russia. Basingtoke: Palgrave Macmillan. https://doi.org/10.1057/9781137395719.

Daugbjerg, Mads. 2009. "Pacifying War Heritage: Patterns of Cosmopolitan Nationalism at a Danish Battlefield Site." International Journal of Heritage Studies 15 (5): 431-446. https://doi.org/10.1080/13527250903072765.

Denton, Kirk A. 2014. Exhibiting the Past Historical Memory and the Politics of Museums in Postsocialist China. Honolulu: University of Hawai'i Press.

Edwards, Sam. 2015. Allies in Memory: World War II and the Politics of Transatlantic Commemoration in Europe, C. 1941-2001. Cambridge: Cambridge University Press.

Ferguson, Natasha N. 2007. "Platforms of Reconciliation? Issues in the Management of Battlefield Heritage in the Republic of Ireland." Journal of Conflict Archaeology 3 (1): 79-94. https://doi.org/10.1163/157407807X257377.

Frost, Mark R., Edward Vickers, and Daniel Schumacher. 2019. "Introduction: Locating Asia's War Memory Boom-A New Temporal and Geopolitical Perspective." In Remembering Asia's World War Two, edited by Mark R. Frost, Daniel Schumacher and Edward Vickers, 124. Abingdon: Routledge.

Gilani, M.A. 2012. "The Malaya Campaign - December 1941-February 1942." Defence Journal 16 (1): 76-83.

Harrison, Mark, ed. 1998. The Economics of World War II: Six Great Powers in International Comparison. Cambridge: Cambridge University Press. https://doi. org/10.1017/CBO9780511523632

Harrison, Rodney. 2010. Understanding the Politics of Heritage. Manchester: Manchester University Press.

Hartmann, Rudi. 2014. "Dark Tourism, Thanatourism, and Dissonance in Heritage Tourism Management: New Directions in Contemporary Tourism Research." Journal of Heritage Tourism 9 (2): 166-182. https://doi.org/10.1080/1743873X.2 013.807266.
Henderson, Joan. 2001. "Heritage, Identity and Tourism in Hong Kong." International Journal of Heritage Studies 7 (3): 219-235. https://doi.org/10.1 080/13527250120079402.

Historic England. 2017a. Battlefields: Registration Selection Guide. Swindon: Historic England.

Historic England. 2017b. Commemorative structures listing section guide. Swindon: Historic England.

Hopkins-Weise, Jeff, and Greg Czechura. 2019. "Memory, Commemoration and World War I: Mephisto, Queensland's Unique 'War Prize'." Queensland History Journal 24 (1): 67-88.

Horner, David. 2002. The Second World War (I) the Pacific. Oxford: Osprey Publishing.

Huang, Shu-Mei, and Hyun Kyung Lee, eds. 2020. Heritage, Memory, and Punishment. Remembering Colonial Prisons in East Asia. Abington: Routledge.

ICOFORT. 2018. ICOFORT Charter on Fortifications and Related Heritage; Guidelines for Protection, Conservation and Interpretation. ICOMOS International Scientific Committee on Fortifications and Military Heritage. https://www.icomos.org/ images/DOCUMENTS/General_Assemblies/GA2020_Sydney/Working_ documents/December_GA2020_Working_Docs/GA202012_6-5_Finaldraft_ ICOMOS_ICOFORT_Charter_EN.pdf.

ICOMOS. 1964. The Venice Charter - La Charte De Venise. Paris: ICOMOS Scientific Journal.

ICOMOS. 1982. Florence Charter on Historic Gardens. Paris: ICOMOS.

Keung, Ko Tim, and Jason Wordie. 1996. Ruins of War: A Guide to Hong Kong's Battlefields and Wartime Sites. Hong Kong: Joint Publishing.

Kishimoto, Kyoko. 2004. "Apologies for Atrocities: Commemorating the 50th Anniversary of WWII's End in the United States and Japan." American Studies International 42 (2-3): 17-50.

Lai, Lawrence W.C., Stephen N.G. Davies, Y.K. Tan, and P. Yung. 2009. "The Gin Drinker's Line: Reconstruction of a British Colonial Defence Line in Hong Kong Using Aerial Photo Information." Property Management 27 (1): 16-41. https://doi.org/10.1108/02637470910932656.

Lai, Lawrence Wai-Chung. 1999. "The Battle of Hong Kong 1941: A Note on the Literature and the Effectiveness of the Defense." Journal of the Hong Kong Branch of the Royal Asiatic Society 39: 115-136.

Lee, Ho-Yin. 2012. "In Defence of Hong Kong's WWII Pillboxes: The Truth About the Gin Drinker's Line." Hong Kong University Bulletin 13 (2). Accessed 7 August 2020. https://www4.hku.hk/pubunit/Bulletin/2012_May_Vol.13_No.2/ research/page4.html.

Lee, Ho-Yin, and Lawrence Wai-Chung Lai. 2019. "Difficulties in Preserving Hong Kong's Military Architectural Heritage." eTVonline, no. 08/10/2020. https:// www.blog.etvonline.hk/blog.php?id=1817

Lee, Hyun Kyung. 2018. "Difficult Heritage' in Nation Building: South Korea and Post-Conflict Japanese Colonial Occupation Architecture. Cham: Springer International Publishing; Palgrave Macmillan.

Lennon, J. John, and Malcolm Foley. 2010. Dark Tourism: The Attraction of Death and Disaster. Andover: Cengage Learning.

Logan, William, and Keir Reeves. 2009. Places of Pain and Shame: Dealing with 'Difficult Heritage'. London: Routledge.

Lowry, Bernard. 2011. "The Gin Drinkers Line: Its Place in the History of Twentieth Century Fortifications". Surveying \& Built Environment 21 (2): 58-68.

Macdonald, Sharon. 2015. "Is 'Difficult Heritage' Still 'Difficult'?" Museum International 67 (1-4): 6-22. https://doi.org/10.1111/muse.12078.

Merrill, Sam, and Leo Schmidt. 2011. "A Reader in Uncomfortable Heritage and Dark Tourism." Brandenburg University of Technology. http://www-docs.tucottbus.de/denkmalpflege/public/downloads/UHDT_Reader.pdf.

Meskell, Lynn. 2002. "Negative Heritage and Past Mastering in Archaeology." Anthropological Quarterly 75 (3): 557-574. https://doi.org/10.1353/anq.2002. 0050.

Mitter, Rana. 2013. Forgotten Ally: China's World War II, 1937-1945. Harcourt: Houghton Mifflin.

Mitter, Rana. 2015. "Forgotten Ally? China's Unsung Role in World War II." CNN Opinion. Accessed 18 Sep 2019. https://edition.cnn.com/2015/08/31/ opinions/china-wwii-forgotten-ally-rana-mitter/index.html

Monro, Mary. 2018. Stranger in My Heart. London: Unbound.

Muzaini, Hamzah. 2006. "Producing/Consuming Memoryscapes: The Genesis/ Politics of Second World War Commemoration in Singapore." GeoJourna 66 (3): 211-222. https://doi.org/10.1007/s10708-006-9030-3.

Muzaini, Hamzah. 2013. "Scale Politics, Vernacular Memory and the Preservation of the Green Ridge Battlefield in Kampar, Malaysia." Social \& Cultural Geography 14 (4): 389-409. https://doi.org/10.1080/14649365.2013.777088. 
Muzaini, Hamzah. 2019. "The State of Malaysian War Memory: 'Postcolonializing' Museums in Perak." In Remembering Asia's World War Two, edited by Mark R. Frost, Daniel Schumacher and Edward Vickers, 107-125. Abingdon: Routledge. https://doi.org/10.4324/9780367111335-4.

Muzaini, Hamzah, and Brenda Yeoh. 2005. "Contesting 'Local' Commemoration of the Second World War: The Case of the Changi Chapel and Museum in Singapore." Australian Geographer 36 (1): 1-17. https://doi.org/10.1080/0004 9180500050789.

Pendlebury, John, Yi-Wen Wang, and Andrew Law. 2018. "Re-Using 'Uncomfortable Heritage': The Case of the 1933 Building, Shanghai." International Journal of Heritage Studies 24 (3): 211-229. https://doi.org/10.1 080/13527258.2017.1362580

Price, Jon. 2005. "Orphan Heritage: Issues in Managing the Heritage of the Great War in Northern France and Belgium." Journal of Conflict Archaeology 1 (1): 181-196. https://doi.org/10.1163/157407705774929006.

Reeves, Keir, Geoffrey Bird, Laura James, Birger Stichelbaut, and Jean Bourgeois, eds. 2016. Battlefield Events: Landscape, Commemoration and Heritage Abingdon: Routledge.

Ryan, Chris, ed. 2007. Battlefield Tourism: History, Place and Interpretation. Oxford: Elsevier. https://doi.org/10.4324/9780080548340.

Saito, Hiro. 2016. The History Problem: The Politics of War Commemoration in East Asia.. Honolulu: University of Hawaii Press. https://doi.org/10.1515/9780824 856779.

Schofield, J. 2009. Vimy Declaration for the Management of Historic Battlefield Terrain. First international workshop on conservation of battlefield terrain, Arras, France.

Seaton, A.V. 1996. "Guided by the Dark: From Thanatopsis to Thanatourism." International Journal of Heritage Studies 2 (4): 234-244. https://doi.org/10.1 080/13527259608722178.

Spence Robinson Ltd. 2016. Heritage Impact Assessment, Block 3 at Old Lei Yue Mun Barracks. Hong Kong: Architectural Services Department http://www.aa b.gov.hk/form/175meeting/175assessment-barracks-a-en.pdf.

Stone, Philip. 2006. "A Dark Tourism Spectrum: Towards a Typology of Death and Macabre Related Tourist Sites, Attractions and Exhibitions." Tourism: An Interdisciplinary International Journal 54 (2): 145-160.

The Hong Kong Institute of Surveyors. 2011. Surveying \& Built Environment: Special Issue to Commemorate the 70th Anniversary of the Battle of Hong Kong, 8 December to 25 December 1941. Hon Kong: The Hong Kong Institute of Surveyors https://www.hkis.org.hk/hkis/general/journal/SBEvol21b.pdf.

The Star. 2006. "Perak to Gazette Kampar Green Ridge." The Star, 26 October 2009. Accessed 11 May 2021. https://www.thestar.com.my/news/nation/2 006/04/18/perak-to-gazette-kampar-green-ridge

The Star. 2009. "Saving Green Ridge." The Star, 19 April 2006. Accessed 11 May 2021. https://www.thestar.com.my/news/nation/2009/10/26/saving-green-ridge

The Star. 2010. "Memorial Built to Honour Fallen Soldiers." The Star, 30 October 2010. Accessed 11 May 2021. https://www.thestar.com.my/news/ community/2010/10/30/memorial-built-to-honour-fallen-soldiers/

Treadell, Vicki. 2018. "High Commission in Malaysia Commemorates 100 Years of Armistice." Accessed 6 May 2019. https://www.gov.uk/government/speeches/ remembrance-sunday-address

Tunbridge, J.E., and Greg J. Ashworth. 1996. Dissonant Heritage: The Management of the Past as a Resource in Conflict. Chichester: Wiley.

Uzzell, David, and Roy Ballantyne. 1998. "Heritage That Hurts: Interpretation in a Post-Modern World." In Contemporary Issues in Heritage and Environmental Interpretation: Problems and Prospects, edited by David Uzzell, 152-171. London: The Stationery Office.

Vickers, Edward. 2019. "Capitalists Can Do No Wrong: Selective Memories of War and Occupation in Hong Kong." In Remembering Asia's World War Two, edited by Mark R. Frost, Daniel Schumacher and Edward Vickers, 129-155. Abingdon: Routledge. https://doi.org/10.4324/9780367111335-5.

Waterton, Emma, and Jason Dittmer. 2016. "Transnational War Memories in Australia's Heritage Field." https://doi.org/10.1177/1329878X15622079.

WHC. 2014. "UNESCO Tentative Lists, Dardanelles and Gallipoli Battle Zones in the First World War." Accessed 3 June 2019. http://whc.unesco.org/en/tenta tivelists/5911

Winter, Jay. 2012. "The Generation of Memory: Reflections on the 'Memory Boom' in Contemporary Historical Studies." Canadian Military History 10 (3): 57-66.

\section{Publisher's Note}

Springer Nature remains neutral with regard to jurisdictional claims in published maps and institutional affiliations.

\section{Submit your manuscript to a SpringerOpen ${ }^{\circ}$ journal and benefit from:}

- Convenient online submission

- Rigorous peer review

- Open access: articles freely available online

- High visibility within the field

- Retaining the copyright to your article

Submit your next manuscript at $\boldsymbol{\nabla}$ springeropen.com 